\title{
Organic carbon balance and net ecosystem metabolism in Chesapeake Bay
}

\author{
W. M. Kemp ${ }^{1, *}$, E. M. Smith ${ }^{1}$, M. Marvin-DiPasquale ${ }^{2, * *}$, W. R. Boynton ${ }^{2}$ \\ 'University of Maryland System, Center for Estuarine and Environmental Studies, Horn Point Environmental Laboratory, \\ PO Box 775, Cambridge, Maryland 21613, USA \\ ${ }^{2}$ University of Maryland System, Center for Estuarine and Environmental Studies, Chesapeake Biological Laboratory, \\ PO Box 38, Solomons, Maryland 20688, USA
}

\begin{abstract}
The major fluxes of organic carbon associated with physical transport and biological metabolism were compiled, analyzed and compared for the mainstem portion of Chesapeake Bay (USA). In addition, 5 independent methods were used to calculate the annual mean net ecosystem metabolism (NEM = production - respiration) for the integrated Bay. These methods, which employed biogeochemical models, nutrient mass-balances and summation of individual organic carbon fluxes, yielded remarkably similar estimates, with a mean NEM of $+50 \mathrm{~g} \mathrm{C} \mathrm{m}^{-2} \mathrm{yr}^{-1}$ ( $\pm \mathrm{SE}=7.5$ ), which is approximately $8 \%$ of the estimated annual average gross primary production. These calculations suggest a strong cross-sectional pattern in NEM throughout the Bay, wherein net heterotrophic metabolism prevails in the pelagic zones of the main channel, while net autotrophy occurs in the littoral zones which flank the deeper central area. For computational purposes, the estuary was separated into 3 regions along the land-sea gradient: (1) the oligohaline Upper Bay (11 $\%$ of total area); (2) the mesohaline Mid Bay ( $36 \%$ of area); and (3) the polyhaline Lower Bay $(53 \%$ of area). A distinct regional trend in NEM was observed along this salinity gradient, with net heterotrophy $\left(\mathrm{NEM}=-87 \mathrm{~g} \mathrm{C} \mathrm{m}^{-2} \mathrm{yr}^{-1}\right)$ in the Upper Bay, balanced metabolism in the Mid Bay and net autotrophy $\left(\mathrm{NEM}=+92 \mathrm{~g} \mathrm{C} \mathrm{m}^{-2} \mathrm{Yr}^{-1}\right)$ in the Lower Bay. As a consequence of overall net autotrophy, the ratio of dissolved inorganic nitrogen (DIN) to total organic nitrogen (TON) changed from DIN:TON = 5.1 for riverine inputs to DIN:TON = 0.04 for water exported to the ocean. A striking feature of this organic C mass-balance was the relative dominance of biologically mediated metabolic fluxes compared to physical transport fluxes. The overall ratio of physical TOC inputs $(I)$ to biotic primary production $(P)$ was 0.08 for the whole estuary, but varied dramatically from 2.3 in the Upper Bay to 0.03 in the Mid and Lower Bay regions. Similarly. ecosystem respiration was some 6 -fold higher than the sum of all physical carbon sinks. This general negative correspondence between $l: P$ ratio and NEM, which occurred among Bay regions, was also evident in data available for organic $C$ fluxes in other coastal ecosystems. An inverse relationship between NEM and $P$, postulated in a previous study, did not apply to Chesapeake Bay, and closer examination of available data revealed the importance of the loading ratio of DIN:TOC as a key control on coastal NEM. It is proposed here that the general global trend of coastal eutrophicatıon will lead to increasing values of NEM in estuaries worldwide. The management implications of this trend are complex, involving both increased potential fisheries harvest and decreased demersal habitat.
\end{abstract}

KEY WORDS: Net ecosystem metabolism Production - Respiration Organic carbon Inorganic nutrients Estuaries Chesapeake Bay

\section{INTRODUCTION}

Rates of organic production in estuaries and other coastal ecosystems are among the highest in the bio-

-E-mail:kemp@hpel.cees.edu

- Present address: U.S. Geological Survey, 385 Middlefield

Rd, Menlo Park, California 94025, USA sphere (Kelly \& Levin 1986). This characteristically rich productivity has been attributed to the relatively high rates of nutrient inputs (Nixon et al. 1986) and to the diversity of functional groups of primary producers, including phytoplankton, benthic micro- and macroalgae, seagrasses and tidal marshes (Odum 1971). In addition to this substantial autochthonous production, many estuarine systems also receive high rates of 
organic loading from external sources in the adjacent watershed (Meybeck 1982, Kempe 1984. Howarth et al. 1996). Much of the river-borne organic matter is, however, composed of relatively refractory dissolved organic carbon, DOC (Meybeck 1982). In addition, for rivers with moderate to high suspended sediment concentrations, most of the particulate organic carbon, $\mathrm{POC}$, is also relatively unavailable for metabolic breakdown (Ittekkot \& Laane 1991) Some estuarine systems, however, receive significant inputs of labile organic matter from external sources, such as wastewater effluents (van Es \& Laane 1982) and adjacent oceanic upwelling areas (Smith et al. 1991).

These inputs of organic carbon to coastal ecosystems may have a variety of fates, depending on their origin, form and relative lability. Significant fractions of the organic inputs to estuaries are consumed by resident heterotrophic organisms, supporting their respiration and growth. There is particular interest in understanding how organic inputs might regulate production and harvest of the valuable coastal fisheries (Houde \& Rutherford 1993), which appear to be characterized by efficient transfer of primary production to commercial yield (Nixon 1988, Costanza et al. 1993). The harvest and emigration of these fish, as well as invertebrates and waterfowl feeding on estuarine food-chains, represent potentially significant loss terms in the organic carbon budget of coastal ecosystems (Houde \& Rutherford 1993). In addition, many coastal systems are considered to be effective traps for inputs of suspended particulates from adjacent watershed and oceanic sources (e.g. Schubel \& Carter 1.984), resulting in accumulation of particulate organic carbon in estuarine bottom sediments. Although most of this POC is consumed and respired by benthic organisms, a substantial fraction may be buried indefinitely (e.g. Roden et al. 1995)

The balance between primary production $(P)$ and total respiration $(R)$ in a particular ecosystem is a measure of both its trophic status (Odum 1956) and availability of autochthonous organic matter for harvest and export to adjacent regions (e.g Fisher \& Likens 1973). For an autotrophic erosystem, in which $P>R$, organic matter will be buried or exported; when $P<R$, the ecosystem is heterotrophic, and its metabolism must be supported by stored or imported organic matter. The net metabolic balance of an ecosystem is indicated by the difference between $P$ and $R$ or the ratio, $P: R$. In general, inorganic nutrients are assimilated and removed from the environment by primary production and regenerated back in respiratory processes. Hence, autotrophic systems tend to require inputs of inorganic nutrients from external sources, while heterotrophic systems regenerate and export nutrients (Smith et al. 1991). Although globally averaged long-term mean rates of primary production and respiration tend to converge (e.g Odum 1956), imbalances in $P$ and $R$ at smaller scales contribute to the functional coupling among adjacent regions via exchanges of inorganic nutrients and organic carbon. Understanding the metabolic balance within plankton communities is useful for predicting POC deposition from pelagic to bonthic subsystems in coastal environments (Kemp \& Boynton 1992, Oviatt et al. 1993, Baines et al. 1994). The $P: R$ ratio is also a useful index for assessing the relative importance of 'new' versus 'regenerated' production in aquatic ecosystems (Quinones \& Platt 1991). Even at a global level, concepts of net ecosystem metabolism can be useful in assessing contributions of specific systems to large-scale carbon budgets (e.g. Smith \& Hollibaugh 1993)

There are a variety of methods which have been used for estimating net ecosystem metabolism (NEM $=P-R$ ) of coastal regions. One of the most common approaches involves analysis and summation of individual rate measurements for primary production and respiration of plankton and benthic communities at specific sites and times (van Es 1977, Garside \& Malone 1978, Jassby et al. 1993). Although this approach allows partitioning overall rates among individual processes and describing temporal and spatial patterns (e.g. Dollar et al. 1991., Smith \& Kemp 1995), it is limited by the need for large data sets and by its tendency to yield large propagated errors from summed rates (e.g. Smith 1991). A related method involves measuring diel or seasonal changes in oxygen or inorganic carbon pools integrated over the whole water column (e.g. Odum 1956, Kenney et al. 1988. Howarth et al. 1996). Large and variable physical transport typical of many coastal waters can, however, generate fluctuations in oxygen concentrations which mask signals associated with $P$ and $R$ (Kemp \& Boynton 1980). Alternative approaches involving biogrochemical models have also been employed successfully to calculate NEM (e.g Nixon \& Pilson 1984, Smith et al. 1991). These models tend to provide wellconstrained integrated estimates of ecosystem metabolism averaged over broad scales, but they are not appropriate for detailed analyses of temporal and spatial patterns.

Although there are surprisingly few direct estimates of net organic carbon metabolism for coastal ecosystems, a recent review of the literature has suggested a preponderance of annual net heterotrophy. especially for the more productive systems (Smith \& Hollibaugh 1993). Indeed, net heterotrophy would be expected for coastal ecosystems receiving large inputs of allochthonous organic matter from its rivers (e.g. Kempe 1984); however, this description may not be consistent with 
the idea of estuaries as traps for particulate organic matter and as sources of bountiful fisheries harvests (e.g. Nixon \& Pilson 1984, Nixon 1988). Direct experiments have demonstrated that increased inputs of inorganic nutrients, without parallel additions of organic carbon, tend to cause increases in both $P$ and NEM for estuarine systems (Oviatt et al. 1986). Within a given water-course along the land-sea gradient, one might expect regional variations in the metabolic balance of ecosystems, where net autotrophic regions transport excess organic matter to adjacent regions which are net heterotrophic (Heath 1995). There are a number of factors which will tend to regulate NEM in an estuarine system, including inputs of inorganic nutrients, exchange rate with the adjacent seaward region, and loading rates and lability of organic carbon (Hopkinson \& Vallino 1995).

Chesapeake Bay (USA) is considered to be among the most productive estuaries worldwide, with exceptionally high rates reported both for algal photosynthesis (Boynton et al. 1982) and fisheries harvest per unit primary production (Nixon 1988). Although an initial calculation of major metabolic and physical organic carbon fluxes was presented over 2 decades ago (Biggs \& Flemer 1972), there are no current published estimates for the Bay's overall balance of organic carbon fluxes. In the intervening years since publication of that preliminary carbon budget, there have been numerous measurements of organic carbon fluxes reported for the Bay, including plankton production and respiration (Malone et al. 1986, 1988, Smith \& Kemp 1995), benthic respiration (Boynton \& Kemp 1985, Roden \& Tuttle 1993, Marvin 1995), and sediment carbon burial (Officer et al. 1984, Dibbs 1988). In addition, many of the most important physical fluxes of nutrients and organic carbon have been calculated using numerical simulation models (Cerco \& Cole 1993), and well-constrained mass-balances have been published recently for nitrogen and phosphorus (Boynton et al. 1995)

The purpose of this paper is to present a robust budget which quantifies the major sources and sinks for organic carbon in the mainstem region of Chesapeake Bay. Here we test the hypothesis that net metabolism in the highly productive Chesapeake Bay ecosystem is heterotrophic (Smith \& Hollibaugh 1993) by comparing calculations of NEM generated from several alternative methods. We consider the relative importance of physical transport versus biological production and consumption processes in the estuary's organic carbon balance. We also contrast regional and seasonal differences in major physical and metabolic carbon fluxes, and consider implications for understanding the Bay's ecological interactions and for managing its resources.

\section{METHODS AND APPROACH}

Overall approach. Three distinct approaches were used to calculate 5 independent estimates of annual net ecosystem metabolism (NEM) for mainstem Chesapeake Bay. These computations are based on substantially different conceptualizations of physical fluxes and biogeochemical processes (Fig 1). In the first of these approaches, broadly aggregated inputs and losses of organic carbon to and from the estuarine ecosystem were organized into physical and biological
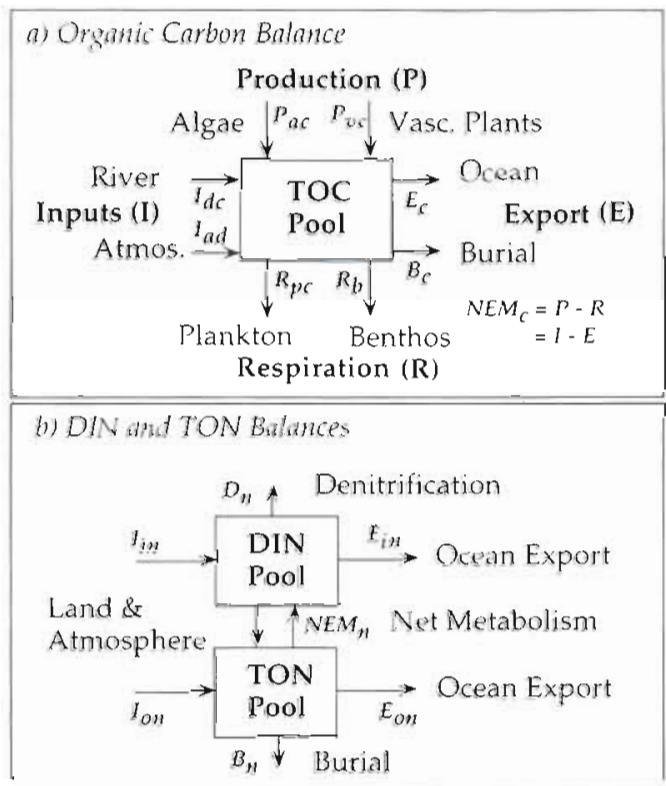

c) DIN and DIP Balances

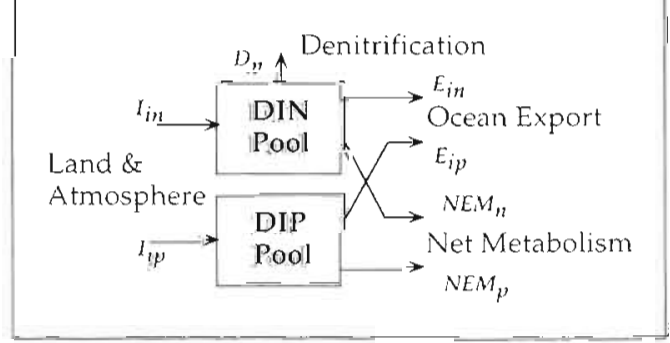

Fig. 1. Schematics of methods used for calculating net ecosystem metabolism (NEM, (C units), NEM ( $N$ units) or NEM ( $P$ units)] of Chesapeake Bay under steady state conditions: (a) organc carbon balance, where $\operatorname{NEM}_{c}=(P-R)=(I-E)$; (b) balances of dissolved inorganic nitrogen (DIN) and total organic nitrogen (TON), where $\mathrm{NEM}_{\mathrm{n}}=\left(I_{\mathrm{n}}-E_{\text {in }}-D_{\mathrm{n}}\right):=\left(I_{\text {on }}-\right.$ $E_{\text {on }}-B_{n}$ ): (c) stoichiometrically related balances of DIN and dissolved inorganic phosphorus (DIP), where NEM $\mathrm{N}_{\mathrm{n}}=\left[I_{\mathrm{in}}-D_{\mathrm{n}}\right.$ $\left.-r\left(I_{i p}\right)\right]\left[1-\left.(I / 16)\right|^{-1}\right.$, with $I_{i p}=$ input of DIP and $r=$ the ratio of DIN:DIP near the estuary mouth, and $\mathrm{NEM}_{\mathrm{n}}=16 \mathrm{NEM}_{\mathrm{p}}$. Subscripts as follows: c, carbon; ac, algal carbon; vc, vascular plant carbon; dc, river discharge of carbon; ad, deposition of atmospheric carbon; pc, planktonic carbon; $b$, benthos; $n$, nitrogen; in, inorganic mitrogen; on, organic nitrogen; p. phosphorus; ip, inorganic phosphorus 
processes (Fig. 1a). NEM was calculated as the summation of all metabolic fluxes, including gross primary production of algal and vascular plant (emergent and submersed) groups $(P)$ and total respiration of planktonic and benthic communities $(R)$. NEM was also estimated from the sum of physical inputs $(I)$ from landbased and atmospheric sources and losses to burial and seaward exchange (which can also be an input). Thus, this approach provides 2 independent estimates of carbon-based net metabolism, where $\operatorname{NEM}_{c}=(P-R)$ and $\mathrm{NEM}_{C}=(I-E)$.

The second and third approaches for estimating ecosystem metabolism involve developing massbalances for nutrients (Fig. 1b, c). In the second method, mass-balances are computed for pools of both dissolved inorganic nitrogen (DIN) and total organic nitrogen (TON), where the net exchange between these 2 pools gives a nitrogen-based estimate of NEM (Fig. 1b). For both DIN and TON pools, inputs from land and atmosphere $\left(I_{\text {in }}\right.$ and $\left.I_{o n}\right)$ must be included along with exchanges between estuary and the sea $\left(E_{\text {in }}\right.$ and $\left.E_{o n}\right)$. Additional losses include denitrification $\left(D_{n}\right)$ for the DIN pool and burial $\left(B_{n}\right)$ for TON $i$ it is assumed that there is no significant burial of inorganic nitrogen (Keefe 1994). This method also provides 2 independent estimates of net metabolism (in nitrogen units), where $\mathrm{NEM}_{\mathrm{n}}=I_{\mathrm{n}}-E_{\mathrm{in}}-D_{\mathrm{n}}$ and $\mathrm{NEM}_{\mathrm{n}}=I_{\mathrm{on}}-E_{\text {ori }}-B_{n}$. Although a similar mass-balance scheme could be developed for phosphorus, the inability to distinguish between burial of inorganic and organic forms of $P$ (Keefe 1994, Conley et al. 1995) complicates the calculation. The third approach (Fig 1c), which is essentially the method of Nixon \& Pilson (1984), provides a fifth independent estimate of NEM. Here, parallel mass-balances are developed for DIN and dissolved inorganic phosphorus (DIP), where $\mathrm{NEM}_{\mathrm{n}}=I_{\mathrm{n}}-E_{\text {in }}-$ $D_{\mathrm{n}}$ and $N E M_{\mathrm{p}}=I_{1 \mathrm{p}}-E_{\mathrm{ip}}$ respectively. This method requires data for estimating the input terms $\left(I_{i n}, I_{i p}\right)$ and for denitrification $\left(D_{n}\right)$, thus leaving 4 unknown values $\left(\mathrm{NEM}_{n}, \mathrm{NEM}_{p}, E_{\mathrm{in}}, E_{\mathrm{ip}}\right)$. The assumption of fixed Redfield stoichiometry between DIN and DIP uptake/recycling in NEM yields a third equation $\left(\mathrm{NEM}_{n}: \mathrm{NEM}_{\mathrm{p}}=\right.$ 16). The fourth equation required for a unique solution derives from assuming that the ratio of DIN to DIP exchange rates with the sea is proportional to the: ratio $(r)$ of their respective concentrations at the estuary mouth $\left(E_{1 n}: E_{10}=r\right)$.

Several assumptions apply to each of these calculations. Most of the data used in computations of NE. I were taken from the time period 1986 to 1993, and while values fluctuate between years with hydrologic and meteorological changes, extremely wet or dry years ( $\pm 50 \%$ of the 50 -year mean riverflow) were not included. Although pools of nutrients and oiganic carbon within the Bay may vary in size from year to year (e.g Boynton et al. 1982), these variations tend to be small compared to the major inputs and losses, thus justifying steady-state assumptions for these mass-balance calculations. Fur all methods, each of the terms in the mass-balances has an associated error, which propagates through the calculation. In most cases, it is difficult to estimate the individual errors, much less the cumulative propayated errors. Because NEM is calculated as the difference between inputs and losses in all of these methods, propagated errors may make it difficult to distinguish this estimate from zero. With some knowledge about the variance and error distributions for each of the major terms of each mass balance, we could construct a bootstrap calculation of errors using Monte Carlo techniques (e.g. Efron \& Tibshirani 1991). In most cases where such approaches have been used, however, the estimates of error distributions themselves have an unquantified uncertainty, which is typically ignored. Therefore, we have not attempted to estimate propagated errors, but instead take the pluralistic approach of computing the same endpoint (NEM) using 5 independent methods.

Study site description. In this paper, the major fluxes and transformation processes involving organic carbon are calculated for the mainstem of Chesapeake Bay (Fig 2). This estuarine ecosystem is defined here as the tidal water extending in length some $300 \mathrm{~km}$ in a north-south direction from Susquehanna Flats to the Bay Bridge-Tunnel, and in width $(5$ to $30 \mathrm{~km}$ ) between mean tidal water-levels and/or the mouths of lateral tributaries. Vertically, the study area is taken to extend from the water surface down to the depth limit for metabolically active sediments; thus, benthic respiration is considered an internal process, while long-term sediment burial is considered a loss from the system. All area-depth-volume relations used in these calculations were taken from previously compiled Bay statistics (Cronin \& Pritchard 1975). Three ecologically distinct regions are defined for the estuary, with the Upper Bay (oligohaline) separated from the Mid Bay (mesohaline) near latitude $39^{\circ} \mathrm{N}$, and Mid and Lower Bay (polyhaline) separated just below latitude $38^{\circ} \mathrm{N}$ (Fig. 2). The upper 2 regions are similar to those defined previously as the northern Bay (Biggs \& Flemer 1972) and the Maryland Bay (Boynton et al. 1995). Major metabolic processes ( $P$ and $R$ ) were measured routinely from 1988 to 1992 at stations (Fig. 2, 'process stations') located within each of the 3 regions; and nutrient and organic carbon pools were measured every 2 to $4 \mathrm{wk}$ at 40 to 50 stations ('EPA Monitoring') and monthly at an additional 18 stations ('NSF Mapping') over the study period (Fig. 2). For each Bay region hypsographic relations were developed for depth versus both water surface area and water vol- 


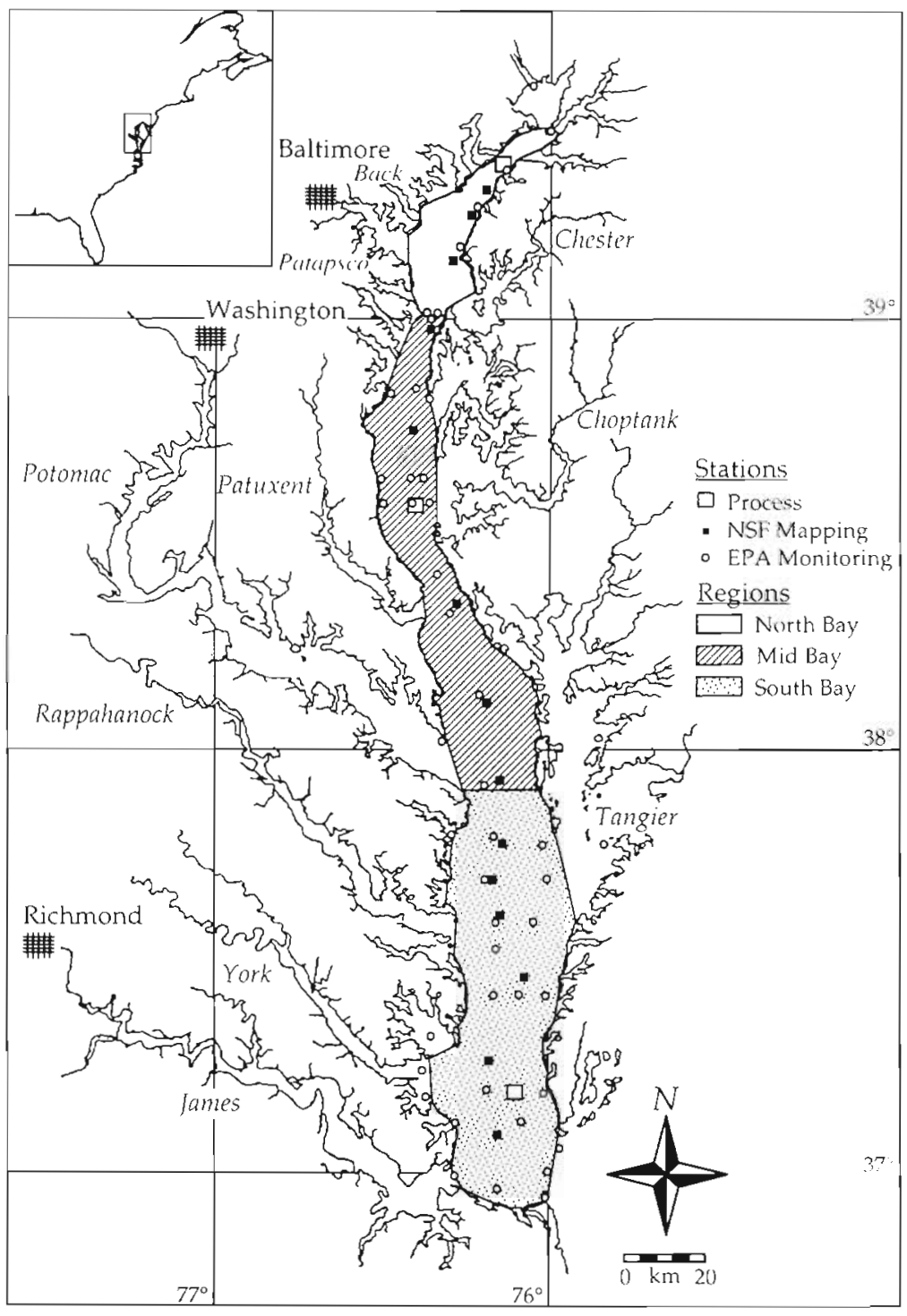

Fig. 2. Map of Chesapeake Bay defining 3 functionally distinct regions (Upper, Mid, and Lower) and showing sampling stations for rate processes ('Process') and for physical, chemical and biological properties measured in monthly ('NSF Mapping') and fortnightly cruises ('EPA Monitorıng') and vertical distributions of algal biomass (Smith \& Kemp 1995). In general, the depth of the euphotic zone $11 \%$ surface irradiance) was slightly shallower $(6$ to $10 \mathrm{~m})$ than the pycnocline depth $(8$ to $12 \mathrm{~m}$ ) in the Mid Bay region and similar to or deeper than the pycnocline (5 to $10 \mathrm{~m}$ vs 3 to $8 \mathrm{~m}$ ) in the Lower Bay; the water column was vertically mixed in the Upper Bay, with a euphotic zone depth of 3 to $4 \mathrm{~m}$. Plankton respiration rates were vertically integrated by multiplying volumetric rates by mean heights of the upper and lower water column layers (e.g. Kemp et al. 1992). Recent estimates of plankton community photosynthetic and respiratory quotients reported Bay-wide mean values of 1.26 and 1.19 , respectively, but neither was significantly different from 1.0 (Stokes 1996). Benthic community respiration was calculated in $\mathrm{O}_{2}$ equivalents as the sum of sulfate reduction rates (assuming the stoichiometric molar relation $\mathrm{O}_{2}: \mathrm{SO}_{4}=2$ ) plus half of the sediment oxygen consumption (SOC) rates (assuming the other half is attributable to sulfide reoxidation). This approach, which has been used previously for the Mid and Lower Bay regions (e.g Roden \& Tuttle 1993), is also appropriate for the Upper Bay because sulfate reduction is still the predominant anaerobic respiratory process, even in this low salinity region (Marvin 1995). A respiratory quotient of 1.0 was used to convert $\mathrm{O}_{2}$ rates into carbon units, based on numerous contemporaneous observations of $\mathrm{O}_{2}$ and total $\mathrm{CO}_{2}\left(\mathrm{TCO}_{2}\right)$ fluxes across the sediment-water interface (P. Sam. pou unpubl.). Rates of sulfate reduction (Roden \& Tuttle 1993, Marvin 1995) and ume to calculate the height of the bottom water layer (below the pycnocline) and to distinguish between littoral and pelagic areas (e.g. Kemp et al. 1992, Smith \& Kemp 1995).

Planktonic and benthic production and respiration. Rates of plankton community production and respiration were based on light:dark bottle incubations using high-precision oxygen titration methods (Smith \& Kemp 1995). Vertically integrated rates of gross primary production, which were estimated as the sum of daytime net production plus dark respiration, were calculated using photosynthesis versus irradiance relations, vertical attenuation of downwelling irradiance
SOC (Cowan \& Boynton 1996) were available for deep (sub-photic) sediments in all 3 regions of the Bay.

The estuarine cross-section was separated into metabolically distinct sections, including pelagic photic and aphotic zones, distinguished by the euphotic depth (depth of $1 \%$ surface irradiance), and littoral zones, where sediment surfaces are above the euphotic depth. Because of the limited availability of data for both benthic (algal) primary production (Rizzo \& Wetzel 1985) and shallow planktonic $P$ and $R$ (e.g. Kemp \& Boynton 1981) in Chesapeake Bay, alternative approaches were developed for estimating metabolic rates in the littoral zone. Annual mean rates of verti- 
cally integrated total primary production were taken to be constant at all depths over a given Bay crosssection. This assumes that, while volumetric rates may vary over depth gradients, vertically integrated areal rates would be constant under light-limited conditions (e.g. Wofsy 1983). This also assumes that the sum of planktonic plus benthic production in the littoral areas is similar to the integrated plankton community production in the adjacent pelagic region, and that the littoral photic zone is simply compressed within the benthic algal habitat (Sand-Jensen 1989, MacIntyre et al. 1996). Recent observations in Chesapeake Bay (Petersen et al. 1997, M. Kemp unpubl.) support these assumptions. On the other hand, volumetric rates of planktonic community respiration were taken to be constant over the cross-section (Kemp \& Boynton 1980, 1981), indicating that densities and activities of heterotrophic organisms did not vary with water column depth (e.g Shiah \& Ducklow 1994). In addition, existing data on sediment-water fluxes of oxygen and total inorganic carbon in the Mid Bay region have revealed that rates in littoral areas ( $<8 \mathrm{~m}$ depth) are consistently lower (by an average of $50 \%$ ) than those measured for the deep pelagic sediments (Kemp unpubl.). Thus, benthic respiration rates in the littoral areas were taken to be half those in adjacent deep sediments.

An estimate of the contributions of submersed vascular plants and low intertidal marsh plants to the Bay's carbon balance was also made. It was assumed that the total respiration associated with these vascular plant habitats was already taken into account in the abovedescribed scheme, so only net plant production was included in this calculation. It was anticipated that these contributions of organic carbon production would be relatively small, because the mainstem Bay' has relatively little bordering intertidal marsh habitat. (Stevenson et al. 1988) and the current abundance and areal coverage of submersed vascular plants is drastically reduced compared to its historical levels (Kemp of al. 1983, Orth \& Moore 1983). Observations on the area of submersed plant coverage (Batiuk et al. 1992) were multiplied by representative rates of net plant production for Upper and Lower Bay regions (Kemp et. al. 1984, Orth \& Moore 1986). Estimates of steady-state contributions from intertidal marshes to the Bay's C balance were obtained by multiplying area of marsh coverage surrounding the mainstem Bay (Stevenson et al. 1988) by a value for mean annual export of organic carbon from coastal marshes of North America (Nixon 1980). Finally, potential contribution of organic matter from eroding marshes was also included in this calculation by multiplying estimates of annual areal loss (Horton \& Eichbaum 1991) by mean values for organic content, bulk density and depth of peat for eroding marshes in the Bay region (Stevenson et aI. 1985)
Nutrient mass-balance calculations. Inputs of DIN, TON and DIP were estimated from the same data set used in developing a recent nutrient budget for Chesapeake Bay (Boynton et al. 1995) To accomplish this, it was necessary to use the original data to partition estimates of total $\mathrm{N}$ and $\mathrm{P}$ inputs into dissolved inorganic and total organic forms. Similarly, data from mapping surveys in a process oriented study (LMER Coordinating Committee 1992) were used to compute partitioning of total nitrogen concentration into pools of ammonium, nitrate (plus nitrite), dissolved organic and particulate organic nitrogen along the main axis of the Bay. Estimates of denitrification, sediment burial, and atmospheric deposition of DIN, TON and DIP were taken directly from Boynton et al. (1995), with adjustments for differences in definition of boundaries. For the mass-balance calculations of DIN and TON, nitrogen exchanges at the Bay mouth and at the mouths of major tributaries were computed from model simulation output for the nominal 'mean' hydroIogical year, 1986 (Cerco \& Cole 1993, C. Cerco pers. comm.). The tributaries considered in this analysis (Potomac, James, York, Rappahannock, and Patuxent, and Patapsco/Back Rivers, Fig. 2), combined with the Susquehanna River, account for $>90 \%$ of the total freshwater runoff to the Chesapeake Bay system. These numerical computations of nitrogen exchange at tho seaward boundaries of the Bay and its major tributaries were remarkably close to those estimated by difference in mass-balance calculations (Boynton et al. 1995).

Physical inputs and losses for organic carbon. Inputs of total organic carbon (TOC) from the Susquehanna River to the mainstem Bay were also calculated from the same data set used in developing nutrient loading estimates (Boynton et al. 1995, R. Sunımers unpubl.). Point source inputs from sewage and industrial effluents were derived from data used for the numerical simulation model (Cerco \& Cole 1993), and physical exchanges at the mouths of the Bay and its major tributaries were computed as output from model simulations for 1986 ( $\mathrm{C}$ Cerco pers. comm.). The same tributaries were included in this analysis as those listed above for nutrient budget calculations. Data from the Bay monitoring program (e.g Magnien et al. 1.992) were used to examine seasonal patterns in the vertical distribution of TOC at mouths of the mainstem Bay and the Potomac estuary and to consider if these were consistent with the computed exchange rates. Organic carbon losses through sediment burial were calculated from the same data set as used previously for nutrient budgets (Boynton et al. 1995), with addition of sediment carbon content (Boynton \& Kemp 1985, W Boynton unpubl. data) and adjustments for differences in definition of Bay area. Estimates of carbon removed from the Bay in fisheries harvest also parallel previous calculations for nutrient budgets (Boynton et al. 1995). 


\section{RESULTS AND DISCUSSION}

\section{Seasonal and regional variations in GPP and $R$}

Seasonal patterns for vertically integrated gross primary production (GPP) of the plankton communities exhibited moderate to strong summer maxima associated with peak water temperatures in all 3 regions of Chesapeake Bay. Rates in the Mid and Lower Bay regions were, however, 6 -fold higher than those in the Upper Bay (Fig 3). These patterns include seasonal peak values for Mid and Lower Bay in July $\left(\approx 5 \mathrm{~g} \mathrm{C} \mathrm{m}^{-2}\right.$ $\mathrm{d}^{-1}$, assuming photosynthetic quotient $=1.2$ ) that are substantially larger than the ${ }^{14} \mathrm{C}$ rates reported previously for these regions (Flemer 1970, Malone et al. $1988,1996)$. These data, which more than doubled the number of observations reported earlier (Smith \& Kemp 1995) for plankton rates, reveal surprisingly consistent seasonal trends among years. Estimates of monthly mean GPP (solid lines in Fig. 3) were developed using individual observations for months with 2

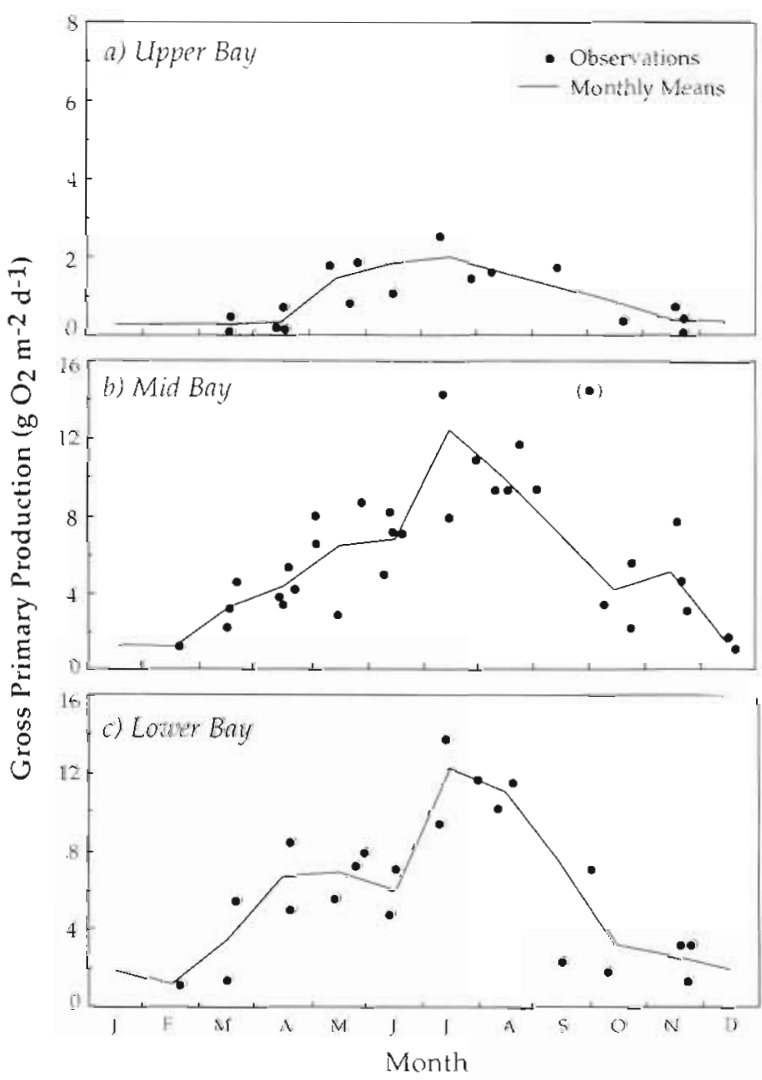

Fig. 3. Seasonal patterns of gross primary production (GPP), measured in pelagic areas of (a) Upper, (b) Mid and (c) Lower regions of Chesapeake Bay. (•) Mean rates measured on specific dates during 1990 to 1992; ( $\longrightarrow$ ) estimated monthly mean values based on observed rates and interpolated rates where no measurements were available

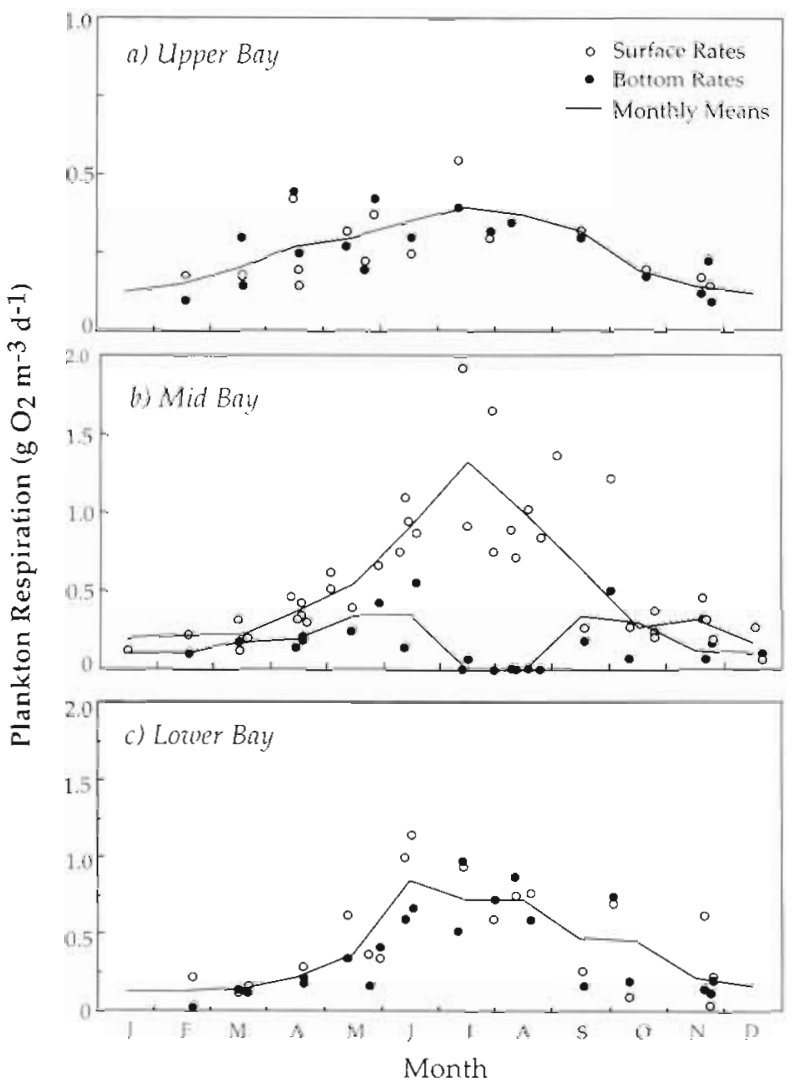

Fig. 4. Seasonal patterns of plankton community respiration $\left(R_{\mathrm{p}}\right)$ for photic $\left(R_{\mathrm{pp}}\right)$ and aphotic $\left(R_{\mathrm{pd}}\right)$ zones (see Fig. 5) measured in pelacic areas of (a) Upper, (b) Mid and (c) Lower regions of Chesapeake Bay. (0) $R_{\mathrm{pp}}$ and $(\bullet) R_{\mathrm{pd}}$ mean rates measured on specific dates during 1990 to 1992; ( $\longrightarrow$ ) estimated monthly mean values based on observed rates and interpolated rates where no measurements were available Values of $R_{\mathrm{pp}}$ and $R_{\mathrm{pd}}$ were statistically indistinguishable for Upper and Lower Bays, so rates were pooled to produce single line

or more rates and by linear interpolation for months with fewer data (e.g. September). One measurement during an anomalous bloom in October at the Mid Bay site (point shown in Fig. 3 in parentheses) was omitted from these estimates. Some details of seasonal patterns, for example the secondary peak in GPP in April at the Lower Bay site (Fig. 3c), are evident despite year-to-year differences

Plankton community respiration $\left(R_{\mathrm{p}}\right)$ rates (volumetric) also exhibited marked seasonal patterns at all 3 stations, with clear summer maxima evident (Fig. 4). As with GPP, respiration rates in the Upper Bay were lower (30 to $80 \%$ ) than those at the other 2 sites. Mean respiration rates (Fig 4, solid lines) were calculated from data for each site and month except September values for Mid and Lower Bay, which were estimated by linear interpolation. There were no significant dif- 
ferences between surface and bottom water respiration rates except in the Mid Bay between April and September (Fig. 4b). Respiration rates appear to peak earlier at the Lower Bay site (June) than in the Upper and Mid Bay regions (July to August). Vertically integrated planktonic community respiration rates were calculated by multiplying measured values (Fig. 4) by respective total volumes and dividing by areas of littoral and pelagic (surface and bottom) zones of each region.

Rates of benthic community respiration $\left(R_{\mathrm{b}}\right)$ exhibited considerable temporal variability and weaker seasonal patterns (compared to $R_{p}$ ) at all 3 study sites (Fig 5). Overall, sulfate reduction (SR) rates tended to be substantially higher at the Mid Bay (Fig. 5b) than at either of the other locations, with lowest values in the Upper Bay. Although these rates of SR are similar to those previously reported for the Mid and Lower Bay regions (e.g. Roden \& Tuttle 1993), these data include the first reports for Upper Bay sites and the most

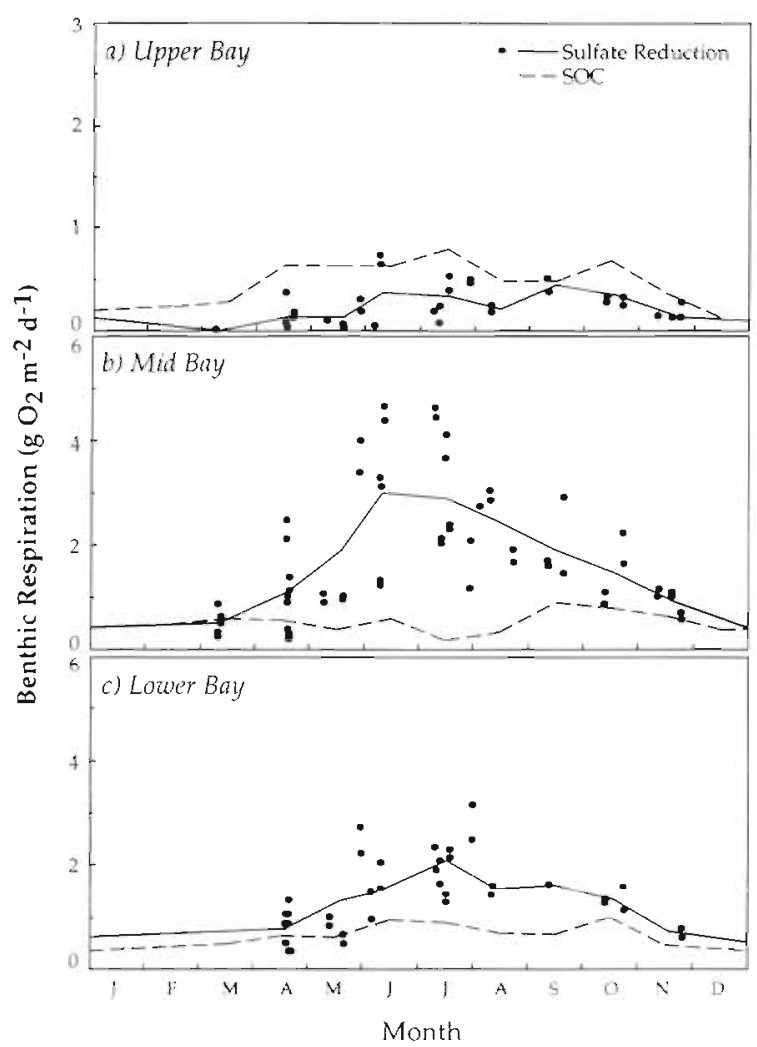

Fig. 5. Seasonal patterns of benthic community respiration as sulfate reduction ( $\mathrm{SR}$, converted to equivalent $\mathrm{O}_{2}$ rates assuming $\mathrm{SO}_{4}: \mathrm{O}_{2}=2$ ) and sediment $\mathrm{O}_{2}$ consumption rates ( $\mathrm{SOC}$ ) in areas underlying pelagic zones of (a) Upper, (b) Mid and (c) Lower regions of Chesapeake Bay. (•) Mean SR rates measured on specific dates during 1990 to 1992; estimated SR (-) and SOC (-- ) monthly mean values based on observed rates and interpolated rates where no measurements were available.

Data from Marvin (1995) and Cowan \& Boynton (1996) detailed descriptions of seasonal cycles (Marvin 1995). Rates of sediment oxygen consumption (SOC, Cowan \& Boynton 1996) were considerably lower than SR at the Mid and Lower Bay sites, but actually exceeded SR in the Upper Bay. Sulfide burial can account for only a small fraction $(<10 \%$, Howarth 1984) of SR excess over SOC. The large difference between SR and SOC in summer at the Mid Bay site (and to a lesser extent in the Lower Bay) is, however, mostly attributable to sulfide efflux from sediments directly into anoxic bottom waters, with subsequent reoxidation near the pycnocline (e.g. Kemp et al. 1992). Presumably, the generally higher value for SOC compared to SR in the Upper Bay can be explained by relatively higher rates of aerobic metazoan respiration. Aerobic respiration accounts for a small fraction of SOC at Mid Bay but may be more important at the macrofauna-rich seaward site (e.g. Mayer 1992). Hence, our estimates of total benthic respiration (which assume that only half of SOC is attributable to aerobic respiration) may slightly underestimate total rates for the Upper and Lower Bay areas while overestimating rates for Mid Bay.

Sediment-water fluxes of dissolved organic carbon have not been included in this analysis: however, these appear to be generally small $(<10 \%)$ relative to total sediment respiration (Burdige \& Homestead 1994). In any case, they would be accounted for in our estumates of $R_{\mathrm{p}}, R_{\mathrm{b}}$ or ocean exchange.

\section{Seasonal and regional variations in NEM}

Integrated rates of organic production and respiration were computed using the monthly mean rates of GPP, $R_{\mathrm{p}}$ and $R_{\mathrm{b}}$ presented in Figs. 3 to 5 , with the assumptions described in 'Methods and approach' (Table 1). During all seasons and particularly the summer months, rates of GPP and total ecosystem respiration $(R)$ were similar in the Mid and Lower Bay regions, but rates for the Upper Bay site were only 20 to $50 \%$ of these values. Values of $R$ exceeded GPP throughout the year in the Upper Bay, and annual mean NEM was strongly net heterotrophic (Fig. 6). Net heterotrophy was maximal in this region in March to April, coincident with the peak delivery of organic carbon with the spring freshet (Smith \& Kemp 1995). Brief periods of net heterotrophy, which were also evident in the Mid and Lower Bay regions in May to June, correspond to the transition from the winter-spring bloom dominated by large centric diatoms to the summer assemblage of diverse flagellated nanoplankters (Sellner 1987, Malone et al. 1988, 1991). The timing of this annual event tends to correspond to the depletion of Si pools in these estuarine zones (Conley \& Malone 1992). A secondary event of net heterotrophy was also evident in the 
Table 1. Summary of annual mean values for gross primary production (GPP), community respiration $\left(R_{\mathrm{p}}\right.$ and $\left.R_{\mathrm{b}}\right)$ and net ecosystem metabolism for 3 regions of mainstem Chesapeake Bay. Vertically integrated rates of GPP (Fig. 6) and volumetric rates of planktonic community respuration $\left(R_{p}\right)$ (see Fig. 7 ) were assumed to be equal in flanks and channel; see text for explanation. Rates of benthic community respiration $\left(R_{b}\right)$ were estimated as sulfate reduction [assuming $\mathrm{O}_{2}: \mathrm{SO}_{4}=2$ (molar)] plus half of sediment $\mathrm{O}_{2}$ consumption (SOC) rates; $R_{\mathrm{b}}$ rates in flank taken as half of channel rates (see Fig. 8); see text for explanation. Areal rates (g $\mathrm{O}_{2}$ $\mathrm{m}^{-2} \mathrm{yr}^{-1}$ ) were estimated by dividing fluxes by respective areas. Subtotals for the total Bay are based on area-weighted sums of regional subtotals

\begin{tabular}{|c|c|c|c|c|c|}
\hline Region & $\begin{array}{c}\text { Area } \\
\left(10^{6} \mathrm{~m}^{2}\right)\end{array}$ & \multicolumn{4}{|c|}{ Metabolic rates $\left(10^{4} \mathrm{~g} \mathrm{O}_{2} \mathrm{y}^{\prime} \mathrm{r}^{\prime}\right)$} \\
\hline \multicolumn{6}{|l|}{ Upper Bay } \\
\hline Pelagic & 310 & 103 & 201 & 48 & -147 \\
\hline Littoral & 296 & 97 & 68 & 23 & +6 \\
\hline $\begin{array}{l}\text { Subtotal } \\
\left(\mathrm{g} \mathrm{O}_{2} \mathrm{~m}^{-2} \mathrm{yr}^{-1}\right)\end{array}$ & 606 & $\begin{array}{c}199 \\
(329)\end{array}$ & $\begin{array}{c}270 \\
(446)\end{array}$ & $\begin{array}{c}72 \\
(118)\end{array}$ & $\begin{array}{l}-141 \\
(-235)\end{array}$ \\
\hline \multicolumn{6}{|l|}{ Mid Bay } \\
\hline Pelagic & 1086 & 2068 & 2037 & 686 & -665 \\
\hline Littoral & 866 & 1649 & 719 & 273 & +657 \\
\hline $\begin{array}{l}\text { Subtotal } \\
\left(\mathrm{g} \mathrm{O}_{2} \mathrm{~m}^{-2} \mathrm{yr}^{-1}\right)\end{array}$ & 1952 & $\begin{array}{c}3717 \\
(1904)\end{array}$ & $\begin{array}{c}2756 \\
(1412)\end{array}$ & $\begin{array}{c}959 \\
(491)\end{array}$ & $\begin{array}{c}+2 \\
(+1)\end{array}$ \\
\hline \multicolumn{6}{|l|}{ Lower Bay } \\
\hline Pelagic & 2151 & 4186 & 3232 & 1153 & -198 \\
\hline Littoral & 805 & 1567 & 427 & 216 & +924 \\
\hline $\begin{array}{l}\text { Subtotal } \\
\left(\mathrm{g} \mathrm{O}_{2} \mathrm{~m}^{-2} \mathrm{yr}^{-1}\right)\end{array}$ & 2956 & $\begin{array}{c}5753 \\
(1946)\end{array}$ & $\begin{array}{c}3659 \\
(1238)\end{array}$ & $\begin{array}{l}1369 \\
(463)\end{array}$ & $\begin{array}{c}+725 \\
(+245)\end{array}$ \\
\hline \multicolumn{6}{|l|}{ Total Bay } \\
\hline Pelagic & 3547 & 6522 & 5420 & 1785 & -1000 \\
\hline Littoral & 1966 & 3442 & 1190 & 471 & +1312 \\
\hline $\begin{array}{l}\text { Subtotal } \\
\left(\mathrm{g} \mathrm{O}_{2} \mathrm{~m}^{-2} \mathrm{yr}^{-1}\right)\end{array}$ & 5514 & $\begin{array}{c}9964 \\
(\mathbf{1 7 5 3 )}\end{array}$ & $\begin{array}{c}6610 \\
(\mathbf{1 2 1 1 )}\end{array}$ & $\begin{array}{l}2256 \\
(435)\end{array}$ & $\begin{array}{c}+312 \\
(+107)\end{array}$ \\
\hline
\end{tabular}

Lower Bay in autumn, perhaps associated with conditions of nutrient limitation (Fisher et al. 1992, Malone et al. 1996) and inputs of seagrass materials associated with late summer senescence and uprooting during frequent storm events (Orth \& Moore 1986).

Computations presented here suggest a strong cross-sectional pattern in NEM throughout the Bay, wherein net heterotrophic metabolism dominates in pelagic zones associated with the main estuarine channel, while net autotrophy occurs in the littoral zones which flank the deeper central area (Fig 6, Table 1). This trend, which derives largely from our assumption of depth-independent production, would be appropriate for conditions of light-limited phytoplankton growth, where algal self-shading dominates light attenuation and suspended sediments have minimal effects (Wofsy 1983, Petersen et al. 1997). While suspended sediments contribute substantially to total light attenuation in the Upper Bay, absorption by algal pigments dominates in most of the Bay (Malone et al. 1996). On the other hand, contributions of benthic algae to total ecosystem production might cause littoral zone GPP to exceed that in adjacent pelagic areas, despite the shoaling euphotic zone (e.g. Macintyre et al. 1996). A second assumption behind this computed pattern is that volumetric rates of plankton community respiration are independent of water column depth, a pattern reported for the Mid Bay area (e.g. Kemp \& Boynton 1980, 1981) These assumptions have been generally corroborated by recent observations in the mesohaline regions of the Bay (Kemp unpubl.) and in experimental ecosystems of varying water depth (Petersen et al. 1997). We provide a sensitivity analysis of these and other assumptions at the end of this section.

A distinct pattern of regional variations in NEM was evident from these data, with net heterotrophy prevailing in the Upper Bay, balanced metabolism in the Mid Bay and net autotrophy in the lower estuary (Fig. 6, Table 1). This is similar to the trend reported previously (Smith \& Kemp 1995) for plankton community metabolism in the pelagic areas along the Bay's main salinity gradient. Net heterotrophy in the Upper Bay results from the combined effects of alloch thonous organic carbon sources and high turbidity conditions enhancing respiration and inhibiting photosynthesis, respectively (Smith \& Kemp 1995). The net autotrophic conditions in the southern estuary appear to result from inputs of inorganic nutrients from Lower Bay tributaries (Boynton et al. 1995) as well as the broad littoral zone which 

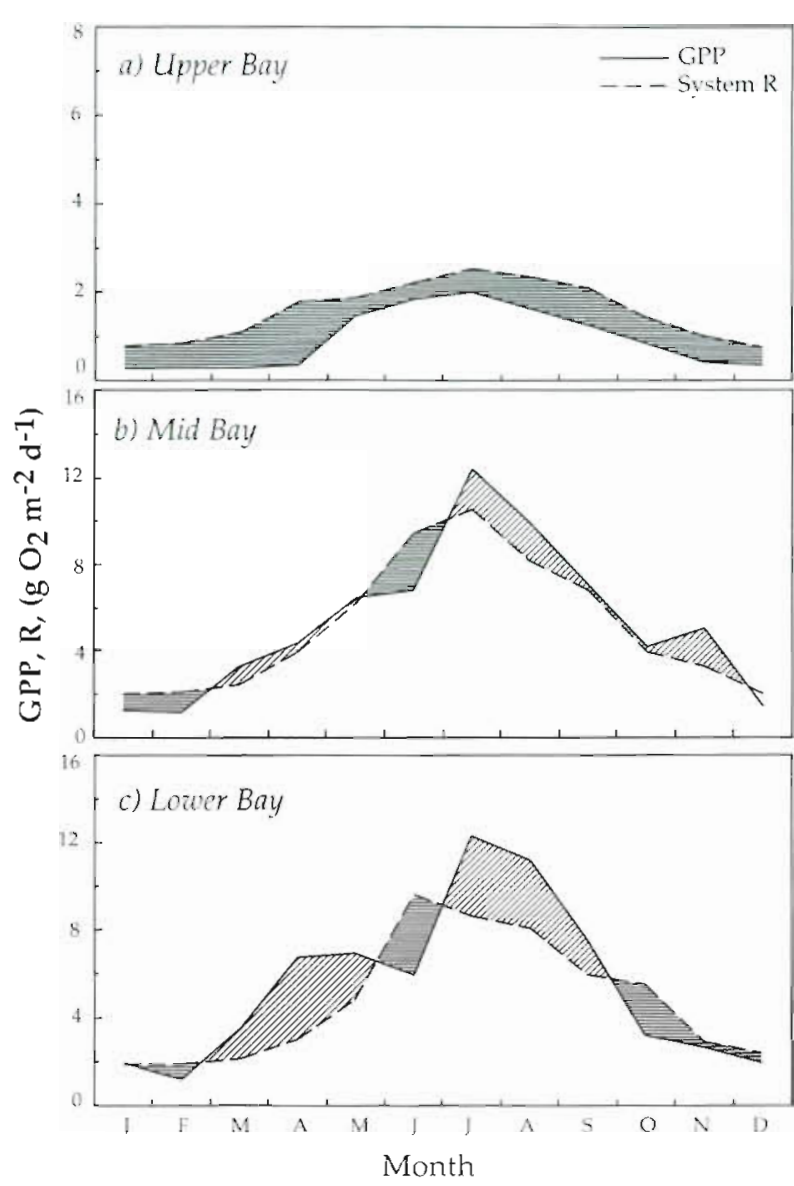

Fig. 6. Estimated seasonal patterns of net ecosystem metabolism (NEM) for (a) Upper, (b) Mid and (c) Lower regrons of Chesapeake Bay; NEM estimated as the sum of littoral and pelagic gross primary production (where vertically integrated rates were assumed equal in 2 areas) minus plankton community respiration in littoral and pelagic photic and aphotıc areas (where volumetric rates (see Fig. 4) were multiplied by respective mean depths of water volumes in each areal minus benthic respiration in pelagic and littoral areas; see text for explanation

flanks a relatively narrow channel. Previous estimates of ecosystem production and respiration for upper and middle Bay regions, although different from those presented here, also suggested strong net heterotrophy in the landward section and minor net autotrophy in the mesohaline region (Biggs \& Flemer 1972). Such transitions from heterotrophic to autotrophic metabolism along land-sea gradients have been also suggested from model-derived patterns proposed for the estuaryshelf region of large coastal systems (Heath 1995) and for the tidal fresh reaches of small marsh-dominated estuaries (Hopkinson \& Vallino 1995).

The potential contributions from production of seagrasses and other submersed vascular plants to the Bay-wide metabolic carbon balance were aiso considered (Table 2). The littoral zone area of the Bay presently occupied by seagrasses and other submersed vascular plants has been recently estimated precisely from aerial surveys (Batiuk et al. 1992). Measurements of net production of plant carbon, which were taken from detailed studies at specific Bay sites (Kemp et al. 1984, Orth \& Moore 1986), may tend to overestimate the mean rates for the whole Bay. The product of these 2 numbers gives an estimate of the total net organic carbon input from submersed plants of $50 \times 10^{9} \mathrm{~g} \mathrm{C} \mathrm{yr}^{-1}$; this estimate already accounts for losses to plant respiration and excretion. When this value is averaged over the whole Bay area, it amounts to only $9 \mathrm{~g} \mathrm{C} \mathrm{m}^{-2} \mathrm{yr}^{-1}$, which is just over $1 \%$ of the Bay's gross plankton production. Although previous calculations indicated that submersed plants contributed approximately one-third to the total ecosystem GPP in a Bay tributary in the 1960s, dramatic declines in plant abundance have greatly reduced this influence (Kemp et al. 1983). Since the present area occupied by seagrasses is about $10 \%$ of its historical habitat (Batiuk et al. 1992), one could speculate that prior to 1960 net production from these plants might have approached $100 \mathrm{~g} \mathrm{C} \mathrm{m}^{-2} \mathrm{yr}^{-1}$

Inputs from emergent vascular plants, including export of both recent plant production and eroding peat from intertidal marshes, appear to contribute even less (than seagrasses) to the mainstem Bay's organic carbon balance. The total input from these combined processes associated with marsh ecosystems was estimated to be $36 \times 10^{9} \mathrm{~g} \mathrm{C} \mathrm{yr}^{-1}$, which is equivalent to $6 \mathrm{~g} \mathrm{C} \mathrm{m}^{-2} \mathrm{yr}^{-1}(<1 \%$ of total), when averaged over the whole Bay area. Previous estimates of marsh export contributions to the Bay's total primary production indicated slightly higher values $(\approx 5 \%$ of total); however, these calculations were for the whole Bay including tributaries with much larger ratios of marsh to open water areas (Nixon 1980).

By summing and area-weighting these measurements of GPP and $R$ for the 3 estuarine regions, a positive (net autotrophy) annual value for net ecosystem metabolism of the whole Bay was estimated to be $108 \mathrm{~g}$ $\mathrm{O}_{2} \mathrm{~m}^{-2} \mathrm{yr}^{-1}$ or $40 \mathrm{~g} \mathrm{C} \mathrm{m}^{-2} \mathrm{yr}^{-1}$ (Table 1). Adding the independent estimates of net organic carbon inputs from macrophytes would increase this value to $55 \mathrm{~g} \mathrm{C}$ $\mathrm{m}^{-2} \mathrm{yr}^{-1}$ The potential problems of uncertain assumptions and error propagation cast substantial doubt on this calculation of NEM. Below we provide sensitivity calculations, which give some perspective for these estimates.

A simple sensitivity analysis allowed us to view the degree to which this estimate depends on key assumptions made in the calculation. Here we varied the following parameters: (1) photosynthetic quotient $(P Q)$, (2) plankton community respiratory coefficient $\left(R Q_{p}\right)$, (3) benthic community respiratory coefficient $\left(R Q_{b}\right)$. (4) relative size of benthic respiration $\left(R_{\mathrm{b}}\right)$ in flank ver- 
Table 2. Annual mean values estimated for net organic carbon production and export from submersed and emergent vascular plant communuties in mainstem Chesapeake Bay

\begin{tabular}{|c|c|c|c|c|}
\hline Community & Process & \multicolumn{3}{|c|}{ 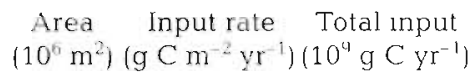 } \\
\hline $\begin{array}{l}\text { Submersed } \\
\text { plants }\end{array}$ & ^.nt plant production & 200 & 250 & 50 \\
\hline $\begin{array}{l}\text { Emergent } \\
\text { plants }\end{array}$ & $\begin{array}{l}\text { Export of plant prod } \\
\text { Annual rate of peat loss }\end{array}$ & $\begin{array}{l}230 \\
0.9\end{array}$ & $\begin{array}{c}100 \\
14000\end{array}$ & $\begin{array}{l}23 \\
13\end{array}$ \\
\hline \multicolumn{3}{|c|}{ Total vascular plant input } & & $\left.5 \mathrm{~g} \mathrm{C} \mathrm{m}^{86} \mathrm{yr}^{-1}\right)$ \\
\hline \multicolumn{5}{|c|}{ 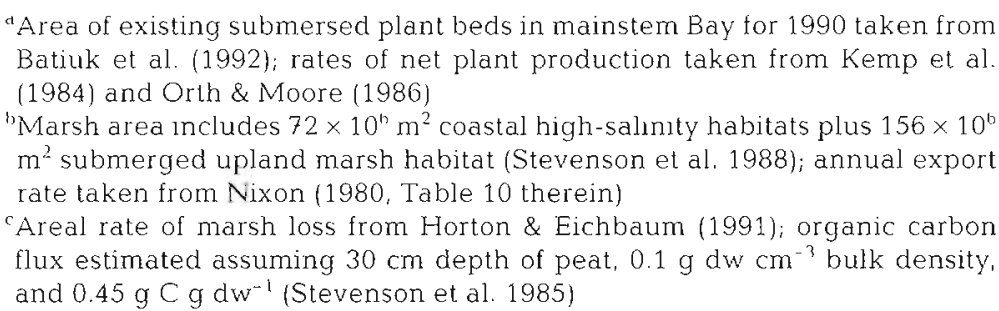 } \\
\hline
\end{tabular}

sus channel regions. Changing $P Q$ from the value of 1.0 used in our base calculation to the often-cited value of 1.25 (e.g. Malone et al. 1986) caused a radical decline in our estimate of NEM from +39 to $-71 \mathrm{~g} \mathrm{C} \mathrm{m}^{-2}$ $\mathrm{yr}^{-1}$ Decreasing either $R Q_{\mathrm{p}}$ or $R Q_{1}$, from the nominal values of 1.0 used here to values of 0.8 (also commonly used in the literature, e.g. Smith \& Kemp 1995) caused substantial increases in NEM from +39 to values of +130 and $+72 \mathrm{~g} \mathrm{C} \mathrm{m}^{-2} \mathrm{yr}^{-1}$, respectively. It is interesting, however, that simultaneous changes in $P Q, R Q_{p}$ or $R Q_{\mathrm{b}}$ to the alternative values indicated above caused very little change in NEM (from +39 to $+53 \mathrm{~g} \mathrm{C} \mathrm{m}^{-2}$ $\mathrm{yr}^{-1}$ ). Alternative assumptions for calculating $R_{\mathrm{b}}$ also lead to considerable changes in estimates of NEM. For example, disregarding the SOC data, and assuming $R_{\mathrm{b}}$ equal to SR rates only causes NEM to increase from +39 to $+71 \mathrm{~g} \mathrm{C} \mathrm{m}^{-2} \mathrm{yr}^{-1}$, while an assumption that $R_{\mathrm{b}}$ was better represented by SOC rates alone increases the NEM estimate further to $+139 \mathrm{~g} \mathrm{C} \mathrm{m}^{-2} \mathrm{yr}^{-1}$ If we assume that values of $R_{b}$, were the same in channel and flank regions (rather than our base case assumption that flank rates were half of channel rates), estimates of NEM decrease from +39 to $+5 \mathrm{~g} \mathrm{C} \mathrm{m}^{-2} \mathrm{yr}^{-1}$. Given the uncertainty in the assumptions used here, it is clear from this analysis that more robust alternative methods are needed for estimating NEM

\section{Nutrient mass-balance estimates of net ecosystem metabolism}

Among the strongest evidence suggesting autotrophic NEM for the mainstem of Chesapeake Bay is seen in the longitudinal distribution of nitrogen species along the Bay's main land-sea transect (Fig 7) An example is given for April 1989 including 4 major nitrogen species: ammonium $\left(\mathrm{NH}_{4}{ }^{+}\right)$, nitrate plus nitrite $\left(\mathrm{NO}_{2}{ }^{-}+\right.$ $\mathrm{NO}_{3}{ }^{-}$), dissolved organic nitrogen (DON) and particulate organic nitrogen (PON). This pattern is similar to others evident in data presented previously for the Bay and its tributaries (e.g. Kemp \& Boynton 1984, Ward \& Twilley 1986, Fisher et al. 1988, Magnien et al. 1992, Boynton et al. 1995), as well as other estuarine systems (e.g. Sharp et al. 1982, Christian et al. 1991). In general, concentrations of total nitrogen tend to decrease nonconservatively as inputs derived from watershed and atmospheric sources are diluted with sea water and taken up in biogeochemical processes with-

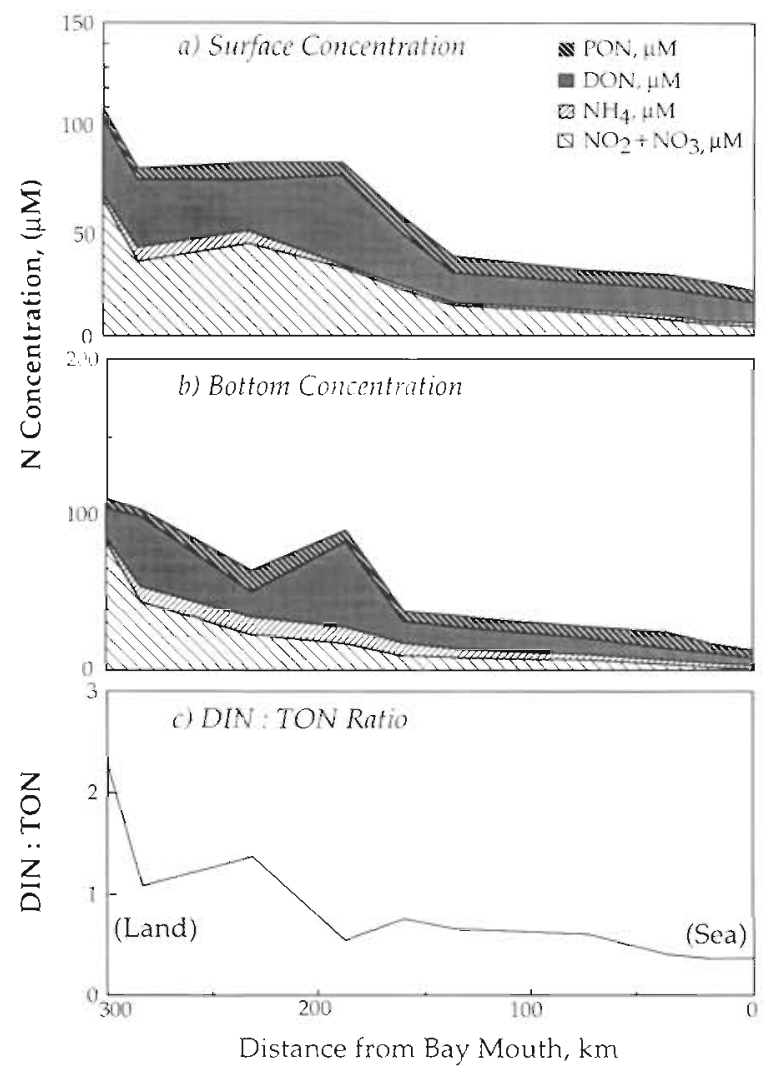

Fig. 7. Longitudinal distribution of DIN $\left(\mathrm{NH}_{4}{ }^{+}, \mathrm{NO}_{2}{ }^{-}+\mathrm{NO}_{3}{ }^{-}\right)$and TON (dissolved, particulate) along the main channel of Chesapeake Bay for April 1989 in (a) surface waters and (b) bottom. waters. (c) Longitudinal distribution of ratio DIN:TON along the main Bay channel (data from Kemp et al. unpubl.) 


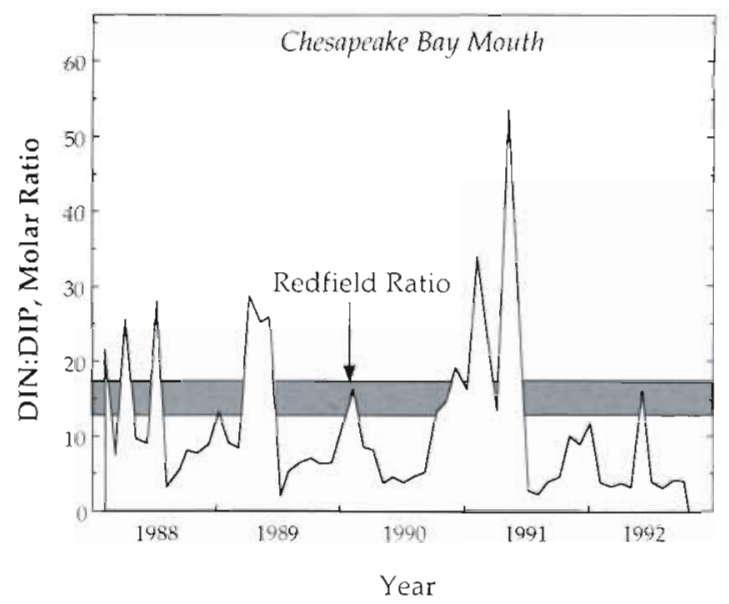

Fig. 9. Monthly mean values for the ratio of DIN:DIP (1988 to 1992) in surface waters (potentially available for export) at monitoring stations near the mouth of Chesapeake Bay; shaded area represents region of Redfield ratio for algal composition (data from EPA monitoring program, e.g. Magnien et al. 1992)

tion (C:N = 6.7 atomic), yielding annual NEM estimates of 33 and $54 \mathrm{~g} \mathrm{C} \mathrm{m}^{-2} \mathrm{yr}^{-1}$, for DIN and TON mass-balances, respectively (Table 3 ). The values are remarkably similar to that calculated from a summation and integration of metabolic rate measurements.

The third approach for computing NEM (in nitrogen units) combines mass-balance calculations for both DIN and DIP (dissolved inorganic phosphorus) pools (Fig. 1c). A key variable in this calculation is the ratio $(r)$ of DIN:DIP for water exchanged at the estuary mouth. This ratio varied between 3 and 55 over the course of a 6 yr data record, with highest values occurring in winter-spring and lowest values in summer, and an overall mean of 10.5 (Fig. 9). Although this ratio does not appear to vary greatly along the estuarine axis in some estuaries such as Narragansett Bay (Nixon \& Pilson 1984), that is not the case for large, river-dominated systems like Chesapeake Bay (e.g. Boynton et al. 1982). The organic carbon equivalent of the NEM value estimated from this method was $75 \mathrm{~g} \mathrm{C} \mathrm{m}^{-2} \mathrm{yr}^{-1}$ (Table 4), which is somewhat higher than the other estimates but still indicates net autotrophy. This method does not require independent calculation of nutrient exchanges between the estuary and the ocean. It does, however, assume net export of both DIN and DIP, and that relative loss rates are proportional to the ratio DIN:DIP in water at the estuarine mouth. Recent nutrient mass-balance calculations concluded that total $\mathrm{P}$ was, in fact, imported from the continental shelf to the Bay (Boynton et al. 1995). It is unclear, however, whether there was a net import or export of DIP, making the present estimate of NEM with this method tenuous.
Table 4. Annual mean net ecosystem metabolism for mainstem Chesapeake Bay estimated based on stoichiometric balances of dissolved inorganic nitrogen, DIN, and dissolved inorganic phosphorus, DIP. For NEM, method adapted from Nixon \& Pilson (1984), where $I_{\mathrm{in}}$ is input of dissolved inorganic nitrogen, $D_{\mathrm{n}}$ is denitrification loss, $I_{\mathrm{pp}}$ is input of dissolved inorganic phosphorus, and $r$ is ratio of DIN:DIP at Bay mouth; see text for explanation

\begin{tabular}{|c|c|}
\hline Variables & $\operatorname{Rates}\left(10^{9} \mathrm{~g} \mathrm{~N} \mathrm{yr}^{-1}\right)$ \\
\hline \multicolumn{2}{|l|}{ Nutrient inputs } \\
\hline \multicolumn{2}{|l|}{ From Susquehnna River ${ }^{\mathrm{d}}$} \\
\hline DIN & 44.23 \\
\hline DIP & 0.34 \\
\hline \multicolumn{2}{|c|}{ From Potomac River and Virginia tributaries ${ }^{b}$} \\
\hline DIN & 6.28 \\
\hline DIP & 0.05 \\
\hline \multicolumn{2}{|l|}{ From Upper Bay point sources ${ }^{b}$} \\
\hline $\mathrm{DIN}$ & 4.65 \\
\hline DIP & 0.57 \\
\hline \multicolumn{2}{|l|}{ From atmosphere } \\
\hline DIN & 5.35 \\
\hline DIP & 0.09 \\
\hline \multicolumn{2}{|l|}{ Total inputs } \\
\hline DIN & 60.51 \\
\hline DIP & 1.05 \\
\hline Losses to denitrification ${ }^{a}$ & 24.30 \\
\hline Ratio $(x)$ 1)IN:DIP at Bay mouth & 10.5 \\
\hline \multicolumn{2}{|c|}{$\begin{array}{l}\text { Net Ecosystem Metabolism, NEM } \\
\quad=\left[I_{1 \mathrm{r}}-D_{\mathrm{n}}-r\left(I_{1 \mathrm{p}}\right)\right]\left[1-\left.(\mathrm{r} / 16)\right|^{-1}\right. \\
\quad=[60.51-24.3-10.5(1.05)](1-10.5 / 16)^{-1}\end{array}$} \\
\hline $\begin{array}{l}\text { aData from Boynton et al. (1995) } \\
\text { 'Data calculated from output o } \\
\text { model (Cerco \& Cole 1993, C. }\end{array}$ & $\begin{array}{l}\text { erical water quality } \\
\text { unpubl.) }\end{array}$ \\
\hline
\end{tabular}

\section{Physical sources and sinks of organic carbon}

The final computation included here for Chesapeake Bay's NEM again uses summation of carbon fluxes; however, in this case physical (rather than biological) sources and sinks of organic carbon were compiled and summed. We reasoned that the steady-state difference between physical inputs and outputs of organic carbon must be attributable to net production or consumption in biological processes (Fig 1c). This calculation deals with physical transport processes which lead to input or removal of organic carbon from the Bay volume, and it includes the physical harvest of fish biomass, in addition to fluxes associated with water transport (Table 5).

The major physical transport source of TOC input to the Bay was from the Susquehanna River, contributing $53 \%$ of the total input to the estuary and $88 \%$ of the total to the Upper Bay region (Table 5). The second largest source of TOC was from the major tributaries, 
Table 5. Summary of annual mean values for organic carbon fluxes associated with physical transport and fisheries harvest for 3 regions of mainstem Chesapeake Bay and attendant estimate of net ecosystem metabolism. Calculations for individual Bay regions do not consider advective and dispersive exchanges between regions

\begin{tabular}{|c|c|c|c|c|}
\hline Fluxes & Upper Bay & Mid Bay & Lower Bay & Total Bay \\
\hline \multicolumn{5}{|l|}{ Organic carbon inputs } \\
\hline Susquehanna river $^{a}$ & 151.3 & 0 & 0 & 151.3 \\
\hline Tributary mouths ${ }^{b^{2}}$ & 17.5 & 34.9 & 46.5 & 98.9 \\
\hline Sources below fall-line & 0.5 & 4.5 & 6.6 & 11.6 \\
\hline Atmospheric deposits & 2.6 & 8.2 & 12.5 & 23.3 \\
\hline Subtotal, inputs & 171.0 & 47.6 & 65.6 & 285.1 \\
\hline \multicolumn{5}{|l|}{ Organic carbon losses } \\
\hline Burial in sediments & 117.0 & 61.2 & 39.1 & 217.3 \\
\hline Export to ocean ${ }^{b}$ & - & - & 281.1 & 281.1 \\
\hline Fisheries harvest & 0 & 0 & 44.8 & 44.8 \\
\hline Subtotal, losses & 117.0 & 61.2 & 365.0 & 543.2 \\
\hline $\begin{array}{l}\text { Net ecosystem metabolism } \\
\qquad\left(\mathrm{gC} \mathrm{m}^{-2} \mathrm{yr}^{-1}\right)\end{array}$ & $\begin{array}{l}-54.9 \\
(-9.9)\end{array}$ & $\begin{array}{l}+13.6 \\
(+2.5)\end{array}$ & $\begin{array}{l}+299.4 \\
(+54.2)\end{array}$ & $\begin{array}{l}+258.2 \\
(+46.8)\end{array}$ \\
\hline $\begin{array}{l}\text { "Data from R. Summers (un } \\
\text { "Calculated from numerical } \\
\text { "Includes both point and dif } \\
\text { "Taken from Boynton et al. } \\
\text { precipitation and } 3.3 \mathrm{~g} \mathrm{C} \\
\text { "Bay regional areas defined } \\
\text { respectively) from Kerhin } \\
\text { computed in Boynton et al. } \\
\text { Lower Bay; see Fig. 11) cal }\end{array}$ & $\begin{array}{l}\text { ee Fig. } 12 \\
\text { Cerco \& Cole } \\
\text { arces below f } \\
\text { pportioned to } \\
\text { fish } \\
\text { able 1, with d } \\
\text { 83). Depositic } \\
\text { Carbon conte } \\
\text { from Bornton }\end{array}$ & $\begin{array}{l}\text { Co pers. co } \\
\text { \& Cole } 19 \\
\text { ay area and } \\
\text { actions } 10.7 \\
0,3.50,3.9 \\
\text { sediment } 13 \\
85 \text {; unpubl. }\end{array}$ & $\begin{array}{l}\text { Nratio of } 6 \mathrm{~g} \\
\text { or Upper, Mir } \\
\mathrm{yr}^{-1} \text { for Uppe } \\
\mathrm{mg} \mathrm{C} \mathrm{g} \mathrm{dw}^{-1}\end{array}$ & $\begin{array}{l}\text { OM in } \\
\text { Bay, } \\
\text { wer Ba.. as } \\
\text { id and }\end{array}$ \\
\hline
\end{tabular}

accounting for some $35 \%$ of the total input to the Bay. While the Susquehanna River debouches directly to the Upper Bay region, the largest inputs from tributary systems occur in the Lower Bay. The other inputs considered in this analysis, including point sources below the river fall-lines and atmospheric deposition, were also highest in the Lower Bay region, but these contributed less than $15 \%$ to the total physical TOC loadings. The distinct 2-layer circulation which develops at the mouths of each of the major tributaries leads to a net seaward transport of surface water and landward transport of bottom water, with the annual mean flows being equal, assuming rainfall and evaporation are in balance (e.g. Pritchard 1952). The question of whether the net transport of TOC will be seaward or landward (to or from the Bay) depends, in part, on the vertical distribution of TOC concentrations. Although non-linearities in transport make it necessary to look at the spatial/temporal details of flow and concentration distributions, higher mean concentrations in the surface layer will tend to yield a net export of TOC from the tributary to the Bay. In general, annual mean concentrations of TOC were, indeed, higher in surface waters for all tributaries considered, including the largest, the Potomac River estuary (Fig. 10b)

The biogeochemical utility of the organic matter delivered to the Bay via physical transport varies depending on its source and timing. TOC input rates from the Susquehanna River (and other tributaries) to the Upper Bay region were more than twice the input from GPP and slightly higher than ecosystem respiration (Tables $1 \&$ 5). For the Mid and Lower Bay regions, however, allochthonous TOC sources represented much smaller fractions ( 3 to $4 \%$ ) of the total organic carbon inputs. Even for the Upper Bay, the strong correlation reported previously between plankton respiration and production (Smith \& Kemp 1995) and the absence of comparable correlations relating riverine TOC imput to respiration (contrast patterns in Figs. 4 or 5 with those in Fig. 8) suggest that autochthonous sources were substantially more labile than allochthonous TOC. On the other hand, the significant positive intercept in the observed regression of plankton respiration on production for the Upper Bay represents almost half the annual mean value for $R_{p}$ and onefourth of the mean daily rate of TOC delivery from the Susquehanna River to this region (Smith \& Kemp 1995). In general, it appears that river-borne organic matter tends to be less labile than that generated from estuarine primary production, and that the relative importance of riverine carbon declines along the landsea salt y cdient (e.g. van Es \& Laane 1982, Matson \& Brinson 1990. Cifuentes et al. 1988).

The 2 major loss terms in this Chesapeake Bay massbalance of physical fluxes of organic carbon were burial in sediments and export to the ocean. Export to 


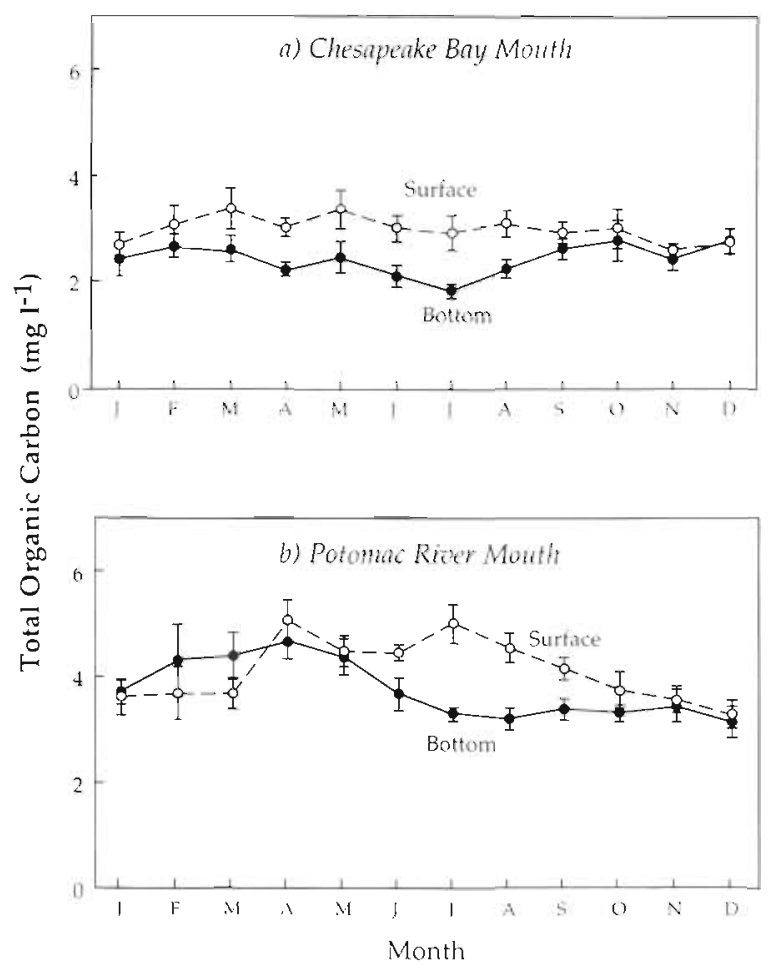

Fig. 10. Mean annual cycles (1984 to 1992) of total organic carbon concentrations in surface and bottom waters at stations near the mouth of Chesapeake Bay and at the confluence of the Potomac River estuary with the mainstem Bay (data from EPA monitoring program, e.g. Magnien et al. 1992)

the continental shelf accounted for almost $52 \%$ of the total physical losses of TOC from the Bay system. The difference between monthly mean surface and bottom concentrations of TOC at the Bay mouth was even more distinct than that shown for the Potomac, with surface values averaging 20 to $60 \%$ higher than bottom concentrations (Fig. 10a). For the whole Bay, burial comprised some $40 \%$ of all physical loss terms for organic carbon, with over half of the total burial occurring in the Upper Bay region (Table 5), even though this represents only $11 \%$ of the total Bay area considered. In fact, the proportions of total organic carbon burial occurring in each of the 3 regions was inversely proportional to their areas (Table 5). The spatial distribution of percent organic carbon in Bay sediments reflects this tendency for highest rates of burial to be concentrated in the upper estuary (Fig. 11). The third physical process of TOC removal from the Bay considered in this analysis is fisheries harvest. The total fresh weight harvest of fish products from the Bay was dominated by the commercial catch of a single species, Atlantic menhaden (Houde \& Rutherford 1993). Fisheries harvest represented a surprisingly large term in this budget, being $8 \%$ of the total losses and $16 \%$ of

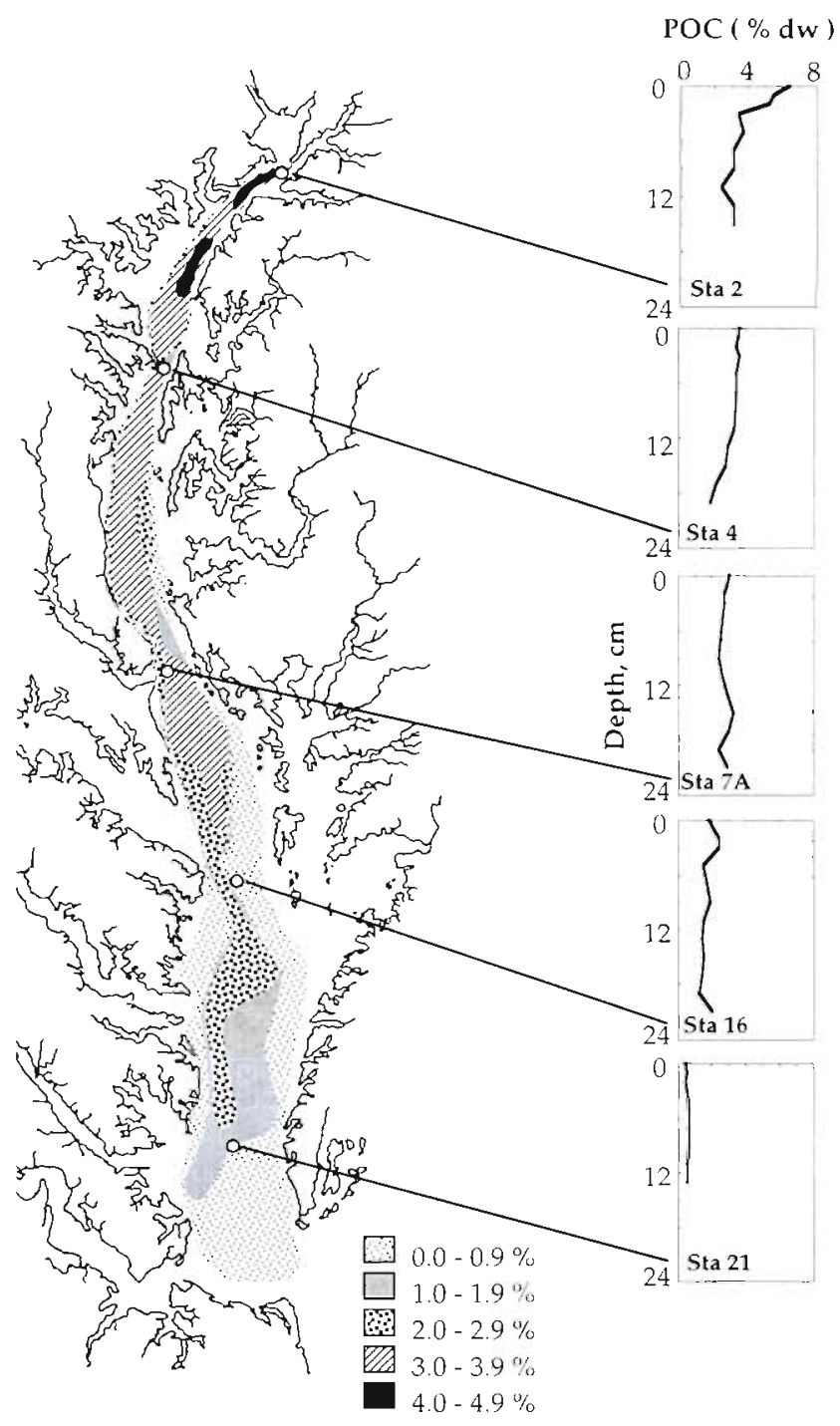

Fig. 11. Spatial patterns (May 1993) of particulate organic carbon (POC, "\% dry weight) in surface sediments (0 to $3 \mathrm{~mm}$ ) of Chesapeake Bay and vertical profiles of POC at selected stations (Aug 1988) along estuarme axis. Data from W. Boynton (unpubl.)

the total physical input fluxes of TOC (Table 5). The value for NEM estimated from the difference between physical input and output fluxes of TOC is $258 \times 10^{9} \mathrm{~g}$ C yr ${ }^{-1}$, which is equivalent to $47 \mathrm{~g} \mathrm{C} \mathrm{m}^{-2} \mathrm{yr}^{-1}$, of which fisheries yield comprised some $17 \%$ (Table 5 ).

\section{Comparison of NEM estimates and C-balance among estuaries}

The 5 independent estimates of NEM for Chesapeake Bay yielded remarkably similar results, with rates ranging from 33 to $75 \mathrm{~g} \mathrm{C} \mathrm{m}^{-2} \mathrm{yr}^{-1}$, and a mean value of $50 \mathrm{~g} \mathrm{C} \mathrm{m}^{-2} \mathrm{yr}^{-1}(\mathrm{SE}=7.5)$. It is interesting that 


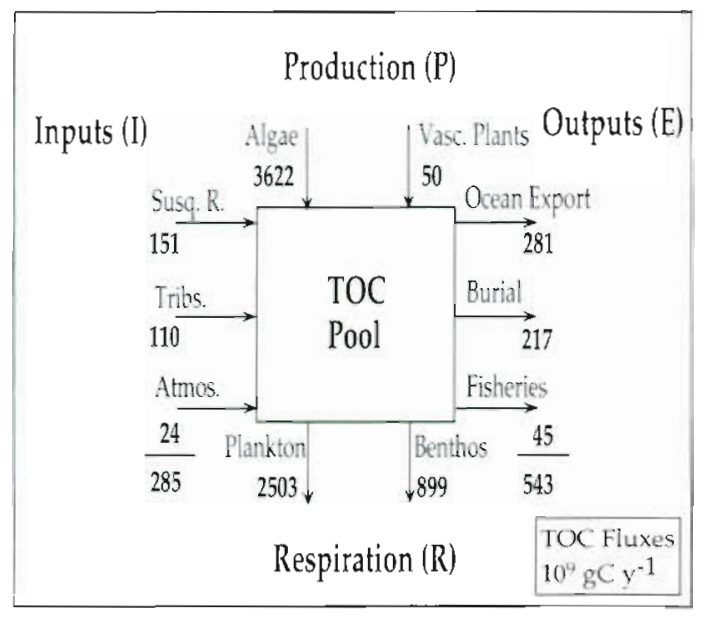

Fig. 12. Summary of estimated annual mean values for major organic carbon fluxes in mainstem Chesapeake Bay, including physical input (I) and output ( $E)$ fluxes and biotic metabolism associated with primary production $(P)$ and community respiration $(R)$. Net ecosystem metabolism can be calculated as $P-R=270 \times 10^{4} \mathrm{~g} \mathrm{C} \mathrm{yr}^{-1}\left(49 \mathrm{gC} \mathrm{m}^{-2} \mathrm{yr}^{-1}\right)$ or as $I-E=$ $258 \times 10^{9} \mathrm{gC} \mathrm{yr}^{-1}\left(47 \mathrm{~g} \mathrm{C} \mathrm{m}^{-2} \mathrm{yr}^{-1}\right)$

the 2 NEM estimates based on $N$ mass-balance (Table 3) and the 2 values for NEM calculated from measured TOC fluxes (biological., Table 1; physical, Table 5) both averaged $44 \mathrm{~g} \mathrm{C} \mathrm{m}^{-2} \mathrm{yr}^{-1}$ Given the fact that the physical TOC fluxes were so much smaller $(10$ to $20 \%$ ) than the biological metabolic fluxes, it is surprising that input-output differences in the 2 budgets converged to similar NEM values (Fig. 12). In fact, the most obvious feature of the overall organic carbon budget for Chesapeake Bay is, perhaps, the dominance of biological compared to physical fluxes. Autochthonous GPP $(P)$ was more than 13 times larger than the sum of all physical transport inputs of TOC $(I)$, while ecosystem respiration was over 6 -fold greater than all of the physical sinks for TOC (Fig 12). The ratio of physical to biological TOC inputs ( $I: P$ ) tends to vary substantially along the land-sea gradient, with values of 2.3 for the Upper Bay declining to 0.03 for the Mid and Lower Bay regions (Tables 1 \& 5). In contrast to the carbon balance, nitrogen assimilated in the Bay's GPP was only 5 -fold greater than the total $N$ inputs from allochthonous sources. This suggests that some $80 \%$ of GPP is supported by recycled nitrogen (e.g. Kemp \& Boynton 1984). While it is impossible to ascertain which fraction of a particular carbon input is channeled into each of the sinks, it can be assumed that most of the carbon generated in GPP is consumed in system respiration. As suggested earlier, indirect evidence indicates that a significant portion of the Upper Bay respiration is supported by river-borne TOC (Smith \& Kemp 1995). Conversely, nitrogen balance calculations (Table 3) suggest that a substantial portion of the seaward exported TOC originated from estuarine production. The Bay's NEM constituted $7.4 \%$ of the calculated GPP for this ecosystem (Fig 12).

Comparing NEM estimated for Chesapeake Bay with values reported for other estuarine ecosystems reveals several interesting relations. A recent study (Smith \& Hollibaugh 1993) included some 22 coastal ecosystems for which sufficient information was available to calculate annual mean NEM. Of these sites, only 7 exhibited NEM values which were positive or zero. Although the data displayed considerable scatter, an inverse relationship between. NEM and GPP was suggested, where the most productive ecosystems had the most heterotrophic metabolism (Smith \& Hollibaugh 1993). This trend of decreasing NEM for the most productive systems was attributed to the fact that most of the nutrients delivered to these estuaries were derived from terrestrial organic matter inputs. Indeed, most of the world's rivers carry substantial loads of TOC (Meybeck 1982, Kempe 1984). This effect, whereby organic loading from land-based sources drives NEM to become negative, is particularly acute because of the fact that $C: N$ ratios for terrestrial plants, and associated detrital organics, are much higher than those of estuarine organisms (e.g. Hopkinson \& Vallino 1995). Hence, use of terrestrial organic matter, with its high $\mathrm{C}: \mathrm{N}$ and $\mathrm{C}: \mathrm{P}$ ratios, to fuel estuarine respiration releases proportionally lower quantities of inorganic nutrients (than would the same respiration on estuarine organic matter) to support coupled production.

On the other hand, increased inputs of inorganic nutrients to estuarine ecosystems tend to stimulate both GPP and NEM. This has been demonstrated clearly in inorganic nutrient enrichment studies with experimental coastal marine ecosystems, where NEM increased from balanced metabolism under low nutrient inputs to $+100 \mathrm{~g} \mathrm{C} \mathrm{m}^{-2} \mathrm{yr}^{-1}$ with a 32 -fold increase in inorganic nutrient loading (Oviatt et al. 1986). The fraction of GPP going to NEM increased from $8.8 \%$ at 2 -fold increase in nutrient loading to $18 \%$ at 32 -fold treatments (Oviatt et al. 1986). Most of this increased NEM could be accounted for as sedimented particulate organic matter and benthic faunal biomass (Oviatt et al. 1993) Chesapeake and Narragansett Bays represent examples of temperate estuaries generating substantial positive NEM from the large inputs of inorganic nutrients received via agricultural runoff and wastewater discharges. Oceanic ecosystems, far from the influence of terrestrial organic matter, appear to exhibit a positive relationship between GPP and NEM (referred to as 'new production', Eppley \& Peterson 1979), which is the opposite of that suggested previously for coastal regions (Smith \& Hollibaugh 1993). Several reef and lagoonal ecosystems under tropical 
oceanic influence have also been shown to have positive NEM supported by efficient nitrogen fixation and trapping of inorganic phosphorus (Smith 1991). Although there are limited systems for which reliable estimates are available for both $I_{1 n}: I_{\text {on }}$ and ecosystem metabolism, it appears that NEM in coastal environments is generally controlled by the relative balance between inputs of inorganic nutrients and organic carbon (Fig. 13). In fact, it is anticipated that other factors, including $\mathrm{C}: \mathrm{N}$ ratio of allochthonous and autochthonous organic matter, water residence-time, and total nutrient loading, would modify this relation between NEM 1 and $I_{\text {In }}: I_{\text {on }}$. Presumably, these other factors do not vary much among the systems represented in Fig. 13.

The number of coastal ecosystems for which a full mass-balance of organic carbon has been computed appears to be small. We identified a total of 7 systems: Chesapeake Bay (this study), Narragansett Bay (Nixon et al. 1995), Tomales Bay (Dollar et al. 1991, Smith et al. 1991, J. Hollibaugh pers. comm.), San Francisco Bay (Jassby et al. 1993), Dollard Estuary (van Es 1977), tidal freshwater Hudson River Estuary (Howarth et al. 1992, 1996), and New York Bight (Garside \& Malone 1978). The ratio of physical TOC inputs to biological production $(I: P)$ varies substantially among these ecosystems, with values ranging from 0.07 for Chesapeake Bay to 7.1 for Dollard Estuary. High values of $I: P$ occur in small estuaries receiving large TOC inputs from land and in the landward sections of larger coastal ecosystems. For Chesapeake Bay, estimated values of I:P declined from 2.3 in the upper estuary to 0.03 in the seaward region. Similarly, $1: P$ decreased from 3.6 to 0.1 between North and South San Francisco Bays and from 1.7 in the upper Hudson River estuary to 0.3 in the Lower Hudson/New York Bight. In general, systems with high values of $I: P$ tended to have low NEM, presumably because respiration is stimulated (to some degree) by physical TOC inputs. Among the 7 systems considered here, there was, on the average, a balance between physical and biological sources of TOC, with the mean $I: P$ approaching 1.0. For all ecosystems included in this comparative analysis, respiration was the largest carbon sink, ranging from 52 to $87 \%$ of the total losses. Sediment burial was consistently the smallest of the 3 organic carbon sinks considered, averaging only $8 \%$ of the total, while seaward export tended to be a larger loss term, ranging from 5 to $40 \%$ of the total for 6 of the 7 systems. Tomales Bay, which was the exception in that it imported TOC from the ocean, may be representative of many small west coast estuaries, influenced by oceanic production on the adjacent narrow continental shelves (Smith et al. 1991). Obviously, more estimates of organic carbon balances are needed for diverse coastal ecosystems for clear general patterns to emerge.

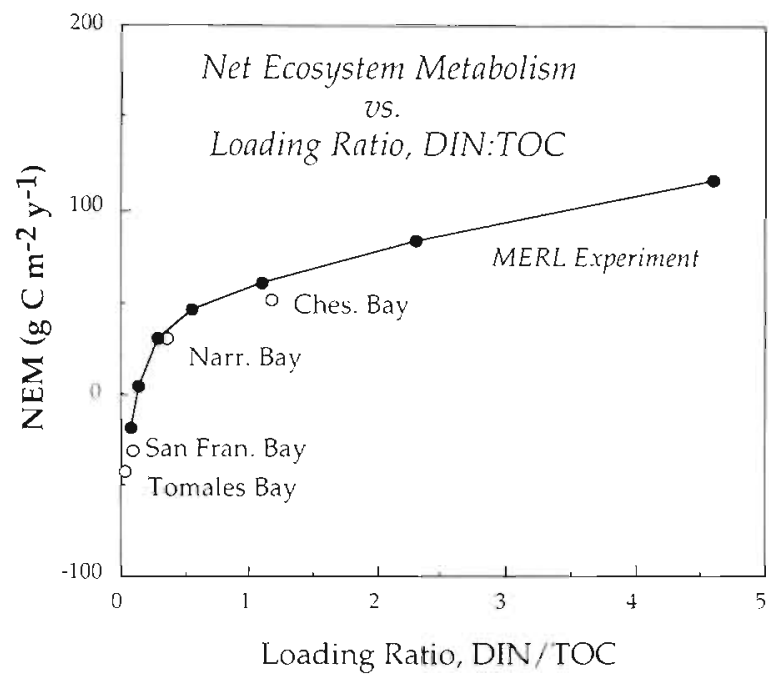

Fig. 13. Comparative analysis of net ecosystem metabolism for estuarine systems in relation to the loading ratio for DIN:TOC. $\bullet$ Data from the experimental marine ecosystems, MERL (Oviatt et al, 1986). (o) Data from selected estuarine ecosystems for which sufficient information is available to be included: Chesapeake Bay (this study), Narragansett Bay (Nixon et al. 1995), San Francisco Bay (Jassby et al. 1993, J. Caffrey pers comm.), and Tomales Bay (Smith et al. 1991, J. Hollibaugh pers. comm.)

These observations on carbon balance for Chesapeake Bay and other coastal ecosystems have implications regarding potential strategies for managing coastal resources. As net production of an estuarine ecosystem (NEM) increases, so does its biomass, which represents increased availability of food to support fisheries harvest from the ecosystem. On the other hand, autotrophic NEM in the photic zone of pelagic estuarine regions also produces particulate organic matter, which is available to sink to bottom waters and support oxygen consumption and, for stratified water columns, oxygen depletion (anoxia). As indicated in earlier discussion, the NEM of an estuarine ecosystem depends largely on the ratio of inorganic to organic nutrient inputs (e.g. Fig. 1, $I_{\text {in }}: I_{\text {on }}$ ), with high ratios favoring autotrophic conditions and low ratios favoring heterotrophy. Although there is strong evidence to suggest that inorganic nutrient loading to Chesapeake Bay has increased over the last several decades (e.g. Magnien et al. 1992, Boynton et al. 1995), it appears that organic matter inputs have changed very little (e.g. Jaworski et al. 1971). Similar eutrophication trends have been documented for coastal ecosystems globally, with widespread increases in inorganic nutrient loading (Billen et al. 1991, Nixon 1995) tied to changes in human population (Peierls et al. 1991), but much smaller and often insignificant changes in TOC loading associated with human activities (Meybeck 
1982, Howarth et al. 1996). Thus, this general trend of increased inorganic nutrient loading, with higher ratios of inorganic:organic inputs, will likely lead to general increases in NEM for Chesapeake Bay and other coastal ecosystems. While waste management efforts in industrial regions focused initially on reducing inputs of organic carbon to coastal waters, present concerns are aimed primarily at removal of inorganic nutrients; however, both can contribute to oxygen depletion (Officer \& Ryther 1977) It appears that resource managers are faced with the inevitable trend of increasing NEM in coastal ecosystems worldwide. They will need to develop strategies for fostering the associated increased production of fisheries populations, while attempting to mitigate potential detrimental effects of anoxia and resulting lost habitat for demersal species.

Acknowledgements. This work was supported by NSF LMER Program. (Grant nos. BSR-8814272 and DEB-9412133) and by NOAA, Maryland Sea Grant College (no. R/P 32). We gratefully acknowledge contributions of J. Cornwell, D. Capone, C Madden, J. Hagy and T. Malone, as well as S. Smith. S. Nixon and $\mathrm{C}$. Hopkinson in discussions which led to the formulation of this manuscript. We thank K. Whipp and D. Hinkle for their assistance in field observations and in preparation of graphics for this manuscript; thanks also go to J Posey and E. Conway for their assistance in data analyses supporting Figs. 9 and 10 . We are particularly indebted to $C$. Cerco for providing output from a numerical simulation model to estimate nutrient and carbon fluxes at the seaward end of the Bay and its major tributaries. Finally, we give special thanks to R. Summers, R Magnien and the U.S. EPA Chesapeake Bay Monitoring Program for use of unpublished monitoring data.

\section{LITERATURE CITED}

Baines SB, Pace M, Karl D (1994) Why does the relationshıp between sinking flux and planktonic primary production differ between lakes and oceans? Limnol Oceanogr 39 $213-226$

Batiuk RA, Orth RJ, Moore KA, Dennison WC, Stevenson JC, Staver L, Carter V, Rybichi N, Kollar S, Bieber S, Heasly P, Bergstrom PW (1992) Chesapeake Bay submersed aquatic vegetation habitat requirements and restoration goals: a technical synthesis. US EPA, Chesapeake Bay Program, Annapolis, $M D$

Biggs RB, Flemer DA (1972) The flux of particularte carbon in an estuary. Mar Biol 12:11-17

Billen G, Lancelot C, Mevbeck M (1991) N, P, and Si retention along the aquatic continuum from land to ocean. In: Mantoura R, Martin JM, Wollast $R$ (eds) Ocean margin processes in global change. J Wiley and Sons, Chichester, p $19-44$

Boynton WR, Garber JH, Summers R, Kemp WM (1995) Inputs, transformations and transport of nitrogen and phosphorus in Chesapeake Bay and selected tributaries. Estuaries 18:285-314

Boynton WR, Kemp WM (1985) Nutrient regeneration and oxygen consumption by sediments along an estuarine salinity gradient. Mar Ecol Prog Ser 23:45-55
Boynton WR, Kemp WM, Keefe CW (1982) A comparative analysis of nutrients and other factors influencing estuarine phytoplankton production. In: Kennedy VS (ed) Estuarine comparisons. Academic Press, New York, p 69-90

Burdige DJ, Homestead J (1994) Fluxes of dissolved organic carbon from Chesapeake Bay sediments. Geochim Cosmochim Acta 58:3407-3424

Cerco CF, Cole T (1993) Three-dimensional eutrophication model of Chesapeake Bay. J Environ Eng 119:1005-1025

Cerco CF, Cole T (1994) Three-dimensional eutrophication model of Chesapeake Bay. Vol 1: Main Report. Tech Rep EL-94-4, US Army Corps of Engineers, Vicksburg, MS

Christian RR, Boyer J, Stanley DW (1991) Multi-year distribution patterns of nutrients within the Neuse River estuary North Carolina. Mar Ecol Prog Ser 71:259-274

Cifuentes LA, Sharp JH, Fogel ML (1988) Stable carbon and nitrogen isotope biogeochemistry in the Delaware estuary. Limnol Oceanogr 33:1102-1115

Conley DJ, Malone TC (1992) Annual cycle of dissolved silicate in Chesapeake Bay: implications for the production and fate of phytoplankton biomass. Mar Ecol Prog Ser 81: $121-128$

Conley DJ, Smith W, Cornwell JC, Fisher TR (1995) Transformation of particle-bound phosphorus at the land-sea interface, Estuar Coast Shelf Sci 40:161-176

Costanza R, Kemp WM, Boynton WR (1993) Predictability, scale and biodiversity in coastal and estuarine ecosystems: implications for management. Ambio 22:88-96

Cowan J. Boynton WR (1996) Sediment-water oxygen and nutrient exchanges along the longitudinal axis of Chesapeake Bay: seasonal patterns, controlling factors and ecological significance. Estuanes 19:562-580

Cronin WB, Pritchard EW (1975) Additional statistics on the dimensions of the Chesapeake Bay and its tributaries: cross-section widths and segment volumes per meter depth. Spec Rep 42, Chesapeake Bay Institute, The Johns Hopkins Univ, Ref 75-3, Baltimore, MD

Dibbs JE (1988) The dynamics of Beryllium-7 in Chesapeake Bay. PhD thesis, State Univ of New York, Binghamton

Dollar SJ, Smith SV, Vink SM, Obredski S, Hollibaugh JT (1991.) Annual cycle of benthic nutrient fluxes in Tomales Bay, California, and contribution of the benthos to total ecosystem metabolism. Mar Ecol Prog Ser 79:115-125

Efron B, Tibshirani R (1991) Statistical data analysis in the computer age. Science 253:390-395

Eppley RW, Peterson BJ (1979] Particulate organic matter flux and planktonic new production in the deep ocean. Nature 282:677-680.

Fisher SG, Likens GE (1973) Energy flow in Bear Brook, New Hampshire: an integrative approach to stream ecosystem metaolism. Ecol Monogr 43:421-439

Fisher TR, Harding LW, Stanley DW, Ward LG (1988) Phytoplankton, nutrients and turbidty in the Chesapeake, Delaware and Hudson Estuaries. Estuar Coast Shelf Sci 27:61-93

Fisher TR, Peele ER, Ammerman JW, Harding LW (1992) Nutrient limitation of phytoplankton in Chesapeake Bay. Mar Ecol Prog Ser 82:51-63

Flemer DA (1970) Primary production in the Chesapeake Bay. Chesapeake Sci 11:117-129

Garside C, Malone TC (1978) Monthly oxygen and carbon budgets of the New York Bight Apex. Estuar Coast Mar Sci 6:93-104

Heath M (1995) An holistic analysis of the coupling between physical and biological processes in the coastal zone. Ophelia 42:95-125

Hopkinson CS, Vallino JJ (1995) The relationships among 
Man's activities in tho watersheds and estuaries: a model of runoff effects on patterns of estuarine communuty metabolism. Estuaries 18:598-621

Horton T, Eichbaum W (1991) Turning the tude. Saving the Chesapeake Bay. Island Press, Washington, DC

Houde ED, Rutherford ES (1993) Recent trends in estuarine fisheries: predictions of fish production and yield. Estuaries $16: 161-176$

Howarth RW (1984) The ecological signuficance of sulfur in the energy dynamics of salt marsh and coastal marme sediments. Biogeochemistry 1:5-27

Howarth RW, Marino R, Garritt R, Sherman D (1992) Ecosystem respiration and organic carbon processing in a large. tidally influenced river: the Hudson River. Biogeochemistry 16:83-102

Howarth RW, Schneider R, Swaney D (1996) Metabolism and organic carbon fluxes in the tidal, freshwater Hudson. Estuaries 19:848-865

Ittekkot V, Laane R (1991) Fate of riverine partıculate organic matter ln: Degens E, Kempe S, Richey R (eds) Scope 42 biogeochemistry of major world rivers. J Wiley and Sons, New York, p 233-242

Jassby AD, Cloern JE, Powell TM (1993) Organic carbon sources and sinks in San Francisco Bay: vanability induced by river flow. Mar Ecol Prog Ser 95:39-54

Jaworski NA, Lear D, Villa O (1971) Nutrient management in the Potomac Estuary. In: Likens GE (ed) Nutrients and eutrophication. ASLO Spec Symp Vol 1. Allen Press Lawrence, KS, p 246-273

Kocte: CW (1994) The contribution of inorganic compounds to the particulate carbon, nitrogen and phosphorus in suspended matter and surface sediments of Chesapeake Bay Estuaries 17:122-130

Kelly JR, Levin SA (1986) A comparison of aquatic and terrestrial nutrient cycling and production processes in natural ecosystems, with reference to ecological concepts of relevance to some waste disposal issues. In: Kullenberg G (ed) The role of the oceans as a waste disposal option. D Reidel Publ Co, New York, p 165-203

Kemp WM, Boynton WR (1980) Influence of biological and physical factors on dissolved oxygen dynamics in an estuarine system: implications for measurement of community metabohsm. Estuar Coast Mar Sci 11:407-431

Kemp WM, Boynton WR (1981) External and internal factors regulating metabolic rates of an estuarine benthic community. Oecologia 51:19-27

Kemp WM, Boynton WR (1984) Spatial and temporal coupling of nutrient inputs to estuarine primary production: the role of particulate transport and decomposition. Bull Mar Sca $35: 522-535$

Kemp WM, Boynton WR (1992) Benthic-pelagic interactions: nutrient and oxygon dynamics. In: Smith D. Leffler $M$, Mackuernan $G$ (eds) Oxygen dynamics in Chesapeake Bay: a synthesis of recent research. Maryland Sea Grant Publication, College Park, p 149-221

Kemp WM, Boynton WR, Twilley RR, Stevenson JC, Means JC (1.983) The decline of submerged vascular plants in upper Chesapeake Bay: summary of results concerning possible causes. Mar Technol Soc J 17:78-89

Kemp WM, Boynton WR, Twilley RR, Stevenson JC, Ward LC (1984) Influences of submersed vascular plants on ecological processes in upper Chesapeake Bay. In: Kennedy VS (ed) The estuaries as a filter. Academic Press, New York p $367-394$

Kemp WM, Sampou PA, Garber J, Tuttle J, Boynton WR (1992) Relative roles of benthic versus planktonic respiration in the seasonal depletion of oxygen from bottom waters of Chesapeake Bay. Mar Ecol Prog Ser 85:137-152

Kempe S (1984) Sinks of the anthropogenically enhanced carbon cycle in surface fresh waters. J Geophys Res 89: $4657-4676$

Kenney BE, Likaker W, Duke CS, Ramus J (1988) Community oxygen metabolism in a shallow tidal estuary. Estuar Coast Shelf Sci 27:33-43

Kerhin R, Halka J, Hennessee E, Blakeslee P, Wells D, Zoltan $N$, Cuthbertson R (1983) Physical characteristics and sediment budget for bottom sediments in the Maryland portion of Chesapeake Bay. US EPA. Washington, DC

LMER (Land Margin Ecosystem Research) Coordinating Commıttee (1992) Understanding changes in coastal environments: the LMER program. EOS 75:481-485

Macintyre H, Geider R, Miller D (1996) Microphytobenthos The ecological role of the 'secret garden' of unvegetated, shallow-water marine habitats. I. Distribution, abundance and primary production. Estuaries 19(2A):186-201

Magnien RE, Summers RM, Sellner KG (1992) External nutrient sources, internal nutrient pools and phytoplankton production in Chesapeake Bay. Estuaries 15:497-516

Malone TC, Conley DJ, Fisher TR, Glibert PM, Harding LW, Sellner KG (1996) Scales of nutrient limited phytoplankton productivity in Chesapeake Bay. Estuaries 19(2B):37 1-385

Malone TC, Crocker LH, Pike SE, Wendler BW (1988) Influences of river flow on the dynamics of phytoplankton production in a partially stratified estuary. Mar Ecol Prog Ser 48:235-249

Malone TC, Ducklow HW, Peele ER, Pike SE (1991) Picoplankton carbon flux in Chesapeake Bay. Mar Ecol Prog Ser 78:11-22

Malone TC, Kemp WM, Ducklow HW, Boynton WR, Tuttle JH, Jonas RB (1986) Lateral varations in the production and fate of phytoplankton in a partially stratified estuary. Mar Ecol Prog Ser 32:149-160

Marvin MC (1995) Controls on the spatial and temporal trends of benthic sulfate reduction and methanogenesis along the Chesapeake Bay central channel. PhD thesis, University of Maryland, College Park

Matson EA, Brinson MM (1990) Stable carbon isotopes and the C:N ratio in the estuaries of the Pamlico and Neuse Rivers, North Carolina. Limnol Oceanogr 35:1290-1300

Mayer MS (1992) Effects of benthic macrofauna on nitrogen cycling and oxygen consumption of estuarine sediments. PhD thesis, University of Maryland, College Park

Meybeck M (1982) Carbon, nitrogen and phosphorus transport by world rivers. Am J Sci 282:401-450

Nixon SW (1980) Between coastal marshes and coastal waters - a review of twenty years of speculations and research on the role of salt marshes in estuarine productivity and water chemistry. In: Hamilton P, MacDonald KB (eds) Estuarine and wetland processes. Plenum Publ, New York, p 437-525

Nixon SW (1988) Physical energy inputs and the comparative ecology of lake and marine and marine ecosystems Limnol Oceanogr 33:1005-1025

Nixon SW (1995) Coastal marine eutrophication: a definition, social causes, and future concerns. Ophelia 41:119-219

Nixon SW, Granger S, Nowicki B (1995) An assessment of the annual mass balance of carbon, nitrogen and phosphorus in Narragansett Bay. Blogeochemistry 31:15-61

Nixon SW, Oviatt CW, Frithsen J, Sullivan B (1986) Nutrients and the productivity of estuaries and coastal marine ecosystems. J Limnol Soc Sth Afr 12:43-71

Nixon SW, Pilson M (1984) Estuarine total system metabolism and organic exchange calculated from nutrient ratios: an example from Narragansett Bay. In: Kennedy VS (ed) The 
estuary as a filter. Academic Press, New York, p 261-290

Odum EP (1971) Fundamentals of ecology. WB Saunders, Philadelphia

Odum HT (1956) Primary production in flowing waters. Limnol Oceanogr 1:1.02-117

Officer CB, Lynch DR, Setlock (i, Helz G (1984) Recent sedimentation rates in Chosapeake Bay. In: Kennedy VS (ed) The estuary as a filter Academic Press, New York, p $131-158$

Officer CB, Ryther JH (1977) Secondary sewage treatment versus ocean outfalls: an assessment. Science 197: $1056-1060$

Orth RJ, Moore KA (1983) An unprecedented decline in submerged aquatic vegetation (Chesapeake Bay). Science 22 $51-53$

Orth RJ, Moore KA (1986) Seasonal and yearly variations in the standing crop of Zosterd marina L. (eelgrass) in lower Chesapeake Bay. Aquat Bot 24:335-341

Ovlatt CA, Doering PH, Nowicki BL, Zoppini A (1993) Net system production in coastal waters as a function of eutrophication, seasonality and benthic macrofaunal abundance. Estuaries 16:247-254

Oviatt CA, Keller AA, Sampou PA, Beatty LL (1986) Patterns of productivity during eutrophication: a mesocosm experiment. Mar Ecol Prog Ser 28:69-80

Peierls B, Caraco N, Pace M. Cole J (1991) Human influence on river nitrogen. Nature 350:386-387

Petersen J, Chen CC, Kemp WM (1997) Scaling aquatic primary productivity: experiments under nutrient and light limited conditions. Ecology (in press)

Pritchard DW (1952) Salinity distribution and circulation in the Chesapeake Bay estuarine system. J Mar Res 11: $106-123$

Quinones RA, Platt T (1991) The relation. between the f-ratio and the $P: R$ ratio in the pelagic ecosystem. Limnol Oceanogr 36:211-213

Rizzo WM, Wetzel RL (1985) Intertidal and shoal benthic community metabolism in a temperate estuary: studies of spatial and temporal scales of variability. Estuaries 8:342-351

Roden EE, Tuttle JH (1993) Inorganic sulfur cycling in mid and lower Chesapeake Bay sediments. Mar Ecol Prog Ser 93:101-118

Roden EE, Tuttle JH, Boynton WR, Kemp WM (1995) Carbon cycling in mesohaline Chesapeake Bay sediments. 1. POC deposition rates and mineralization pathways. J Mar Res 53:799-819

Sand-Jensen K (1989) Environmental variables and their effect on photosynthesis of aquatic plant communitıes. Aquat Bot 34:5-25

This article was submitted to the editor
Schubel JR, Carter H (1984) The estuary as a filter for finegrain suspended sediment. In: Kennedy VS (ed) The estuary as a filter. Academic Press, New York, p 81-129

Sellner K (1987) Phytoplankton in Chesapeake Bay: role in carbon, oxygen and nutrient dynamıs. In: Majumdar SK, Hall JL, Austin HM (eds) Contaminant problems and management of Iiving Chesapeake Bay resources. The Pennsylvania Academy of Science Publications, Easton, p $134-157$

Sharp JH, Culberson CH, Church TM (1982) The chemistry of the Delaware estuary. General considerations. Limnol Oceanogr 27:1015-1028

Shiah FK, Ducklow HW (1994) Temperature and substrate regulation of bacterial abundance, production and specific growth rate in Chesapake Bay, USA. Mar Ecol Prog Ser 103:297-308

Smith SV, Hollibaugh JT, Dollar SJ, Vink S (1991) Tomales Bay metabolism C-N-P stoichiometry and ecosystem heterotrophy at the land-sea interface. Estuar Coast Shelf Sci 33:223-257

Smith SV (1991) Stoichiometry of C:N:P fluxes in shallow-water manne ecosystems. In: Cole J, Lovett J, Findlay S (eds) Comparative analyses of ecosystems. Patterns, mechanisms, theories. Springer-Verlag. New York, p 259-286

Smith SV, Hollibaugh JT (1993) Coastal metabolism and the oceanic organic carbon balance. Rev Geophys 31:7.5-89

Smith EM, Kemp WM (1995) Seasonal and regional varlations in plankton community production and respiration for Chesapeake Bay. Mar Ecol Prog Ser 116:217-231

Stevenson JC, Kearney MS, Pendleton EC (1985) Sedimentation and erosion in a Chesapeake Bay brackish marsh system. Mar Geol 67:213-235

Stevenson JC, Ward LG, Kearney MS (1988) Sediment transport and trapping in marshsystems: implications of tidal flux studies. Mar Geol 80:37-59

Stokes C (1996) Influences of environmental variables on photosynthetic and respiratory quotients in Chesapeake Bay. MSc thesis, University of Maryland, College Park

Van Es FB (1977) A preliminary carbon budget for a part of the Ems estuary: the Dollard. Helgol Meeresunters 30: 283-294

Van Es FB, Laane RWP (1982) The utility of organic matter in the Ems-Dollard estuary. Neth J Sea Res 16:300-314

Ward LG, Twilley RR (1986) Seasonal distributions of suspended particulate material and dissolved nutrients in a coastal plain estuary. Estuaries 9:156-168

Wofsy SC (1983) A simple model to predict extinction coefficients \& phytoplankton biomass in eutrophic waters. Limnol Oceanogr 28:1144-1155

Manuscript first received: September 16, 1996

Revised version accepted: March 3, 1997 